Research Article

\title{
Sizing Algorithm for a Photovoltaic System along an Urban Railway Network towards Net Zero Emission
}

\author{
Prabath J. Binduhewa \\ Department of Electrical and Electronic Engineering, Faculty of Engineering, University of Peradeniya, 20400, Sri Lanka \\ Correspondence should be addressed to Prabath J. Binduhewa; prabathb@pdn.ac.lk
}

Received 15 February 2021; Accepted 1 November 2021; Published 2 December 2021

Academic Editor: Kok Keong Chong

Copyright (c) 2021 Prabath J. Binduhewa. This is an open access article distributed under the Creative Commons Attribution License, which permits unrestricted use, distribution, and reproduction in any medium, provided the original work is properly cited.

\begin{abstract}
A reliable transportation system is essential for the development of a community. Especially in urban transportation, rail transportation is a faster, more comfortable way to travel for the commuters. These benefits can be valued further when the rail transportation system is with zero emissions. Electric trains can be considered a zero-emission transportation method. However, a rail transportation system operates with net-zero emissions when electricity is generated from zero-emission-based sources. Photovoltaic systems have already been integrated into railway stations and spare land owned by railways to achieve net-zero emissions. Furthermore, medium-voltage DC network and microgrid concepts have been proposed to incorporate more renewable energy sources into railway electrification systems. However, the energy generated from those systems is not enough to realise net-zero emissions, as the power requirements of an urban railway electrification system are high. Accordingly, this article investigates the possibility of implementing a photovoltaic system along the railway tracks to meet the energy demands of an urban railway electrification system so that net-zero emissions can be achieved. Other significant advantages of the proposed photovoltaic system are lower feeder losses due to distributed photovoltaic systems integrated into the railway electrification system, lower conversion losses due to the direct integration of the photovoltaic system into the railway electrification system, and the nonrequirement of additional space to install the photovoltaic system. In this paper, a photovoltaic system capacity sizing algorithm is proposed and presented by considering a railway electrification system, the daily schedule of trains, and historical photovoltaic weather data. This proposed photovoltaic system capacity sizing algorithm was evaluated considering a section of the urban railway network of Sri Lanka and a three-year, 2017-2020, photovoltaic weather data. The results indicated that the potential for photovoltaic generation by installing photovoltaic systems along a railway track is much higher than the requirement, and it is possible to meet the required train scheduling options with proper sizing. Furthermore, in the three-year analysis, it is possible to achieve $90 \%$ of the energy required for the railway electrification system with effective train scheduling methods.
\end{abstract}

\section{Introduction}

A reliable transportation network is essential for the development of a country. Existing transportation methods include public vehicles such as buses; personal vehicles such as cars, vans, and bikes; and rail transportation. Rail transportation is more attractive to the public, as it is more convenient than other methods [1]. Electric railway systems are beneficial due to lower power consumption and greenhouse gas emissions compared to traditional fossil fuel-based railway systems [2-5]. Electric trains are zero-emission vehicles, which do not generate harmful emissions during their operation [6]. Although zero-emission vehicles do not produce harmful emissions while operating, emissions may occur at a different location depending on the method of producing electricity. Thus, it is essential to generate electricity with zero emissions to meet the requirements of net-zero emissions in rail transportation. To achieve zero emissions, renewable energy sources are considered the alternative to fossil fuel-based electricity generation. Among renewable energy sources, photovoltaic systems are popular and are rapidly being integrated as a power source in many applications. 
The use of photovoltaic energy in the transportation sector is investigated on a large scale. When considering railway electrification systems, photovoltaic systems are implemented around railway stations and coupled to the feeder network of the railway electrification system [7-9]. The concept of "zero-emission stations" was investigated in Japanese railway stations by integrating photovoltaic systems [10]. Battery storage integrated into the railway stations is used to achieve "zero-emission stations." A $200 \mathrm{~kW}$ and $453 \mathrm{~kW}$ photovoltaic system is implemented on the Takasaki and Tokyo railway stations $[10,11]$. The power generated from the photovoltaic system on station rooftops can be stepped up so the power can be integrated into the railway electrification system [11]. A rooftop photovoltaic system on a train is investigated to operate lighting and fan loads [12]. Such rooftop-mounted electric trains also operate commercially $[13,14]$. In Belgium, a two-mile-long rail tunnel with 16000 photovoltaic panels was implemented to supply power to the railway electrification system. This system is capable of generating 3.3 MWh $[13,15]$. A solar railcar, developed in Hungary, is also currently operating $[13,16]$. India plans to set up photovoltaic systems in railways to generate the necessary energy for the railway electrification system $[17,18]$.

Investigations of future renewable energy railway electrification systems are conducted in microgrids and mediumvoltage DC (MVDC) networks. Future railway electrification systems based on a microgrid architecture with photovoltaic and energy storage are presented in [19]. The railway electrification system gets power through a $220 \mathrm{kV}_{\mathrm{ac}}$ grid, and the substations consist of a battery-supercapacitor storage system. Microgrids consisting of photovoltaic and batterysupercapacitor hybrid storage are connected to the railway electrification system at different points. The microgrid is connected to the $10 \mathrm{kV}$ distribution network. A photovoltaic integrated $24 \mathrm{kV}$ railway electrification system is presented in [5]. This paper states that a photovoltaic system installed in parallel with a railway line can yield $40 \mathrm{MW}$ of peak power from a $400 \mathrm{~km}$ line. Moreover, the authors in [20] have presented the ability to use the MVDC grid network with renewable energy (wind and solar) and battery storage. Lower losses and the ability to integrate renewable energy sources easily are the critical points considered when selecting MVDC over MVAC systems. Interconnected microgrids are considered a possible option to improve the resilience of railway electrification systems [2]. The structure of microgrids can be an AC/DC hybrid. A voltage source converter-based MVDC railway electrification system that can be extended to incorporate renewable energy and battery storage is presented in [3]. The authors of [21] have studied the stability issues of integrating large-scale photovoltaic systems into railway electrification systems at $24 \mathrm{kV}_{\mathrm{dc}}$.

The integration of photovoltaic energy into a railway electrification system was limited by 2018 , as indicated in [22]. The authors of the paper have discussed five configurations that can be used to integrate photovoltaic into a railway electrification system. In all five cases presented, photovoltaic systems are integrated into high-voltage AC systems or medium-voltage AC railway electrification systems at the substation. A back-to-back converter structure for a $25 \mathrm{kV}_{\mathrm{ac}}$ railway electrification system is proposed in [23] to integrate a photovoltaic system. The concept of an MVDC structure for a railway electrification system connecting wind and solar systems, cities, HVDC systems, and an AC grid is presented in [24]. Furthermore, the authors in [25] present an MVDC structure that can integrate renewable energy. It is clear from the literature review that photovoltaic integration into railway electrification systems is limited, and investigations are conducted to find suitable technologies. Moreover, the possibility of installing photovoltaic systems along the railway electrification system has not been thoroughly investigated. Furthermore, research on using photovoltaic system to achieve net-zero emissions has not been conducted. Research on photovoltaic system in railway electrification systems to achieve zero emissions is essential to develop a green railway system.

Although photovoltaic systems could be a possible solution to reach zero emissions, identifying a suitable location to implement a photovoltaic system to power railway electrification systems could be an issue. An electric train needs a significant amount of power, varying from 300 to $1000 \mathrm{~kW}$ $[13,26]$. Typically, a $5-10 \mathrm{~m}^{2}$ area is required for a $1 \mathrm{~kW}$ photovoltaic system [27]. Thus, meeting the energy requirements of a low-power commuter electric train would require a space of $3000 \mathrm{~m}^{2}$. Since a railway network consists of multiple electric trains operating simultaneously, an urban railway electrical systems' total power and energy requirements would be much higher than the values mentioned. Therefore, locating a space to implement a largescale photovoltaic system would be extremely difficult in an urban area to realise zero emissions.

This article investigates the possibility of implementing a photovoltaic system along a railway track to produce the required energy to operate electric trains in an urban railway network to achieve net-zero emissions. The railway tracks are open and exposed to direct sunlight most of the time. Therefore, implementing a photovoltaic system along the rail track would provide clean energy and space to implement a photovoltaic system. Furthermore, with the ability to directly integrate the photovoltaic system into the railway electrical system, the feeder losses and power conversion losses will be reduced, which are additional benefits. The presentation of an algorithm to size the capacity of a photovoltaic system installed along a railway network to achieve net-zero emissions over a year is the main contribution of this paper. The structure of this paper is as follows: initially, a brief review of the electric railway system and the photovoltaic system is provided. Subsequently, a methodology to estimate the maximum possible photovoltaic integration is presented, followed by the proposed algorithm to size the photovoltaic system's capacity. Finally, the methodology is verified considering an urban railway network in Sri Lanka and weather data for three years in the region.

\section{Proposed Generalized Railway Electrification System with Photovoltaics}

Figure 1 presents a block diagram of the existing and proposed electric railway network. In the existing railway 


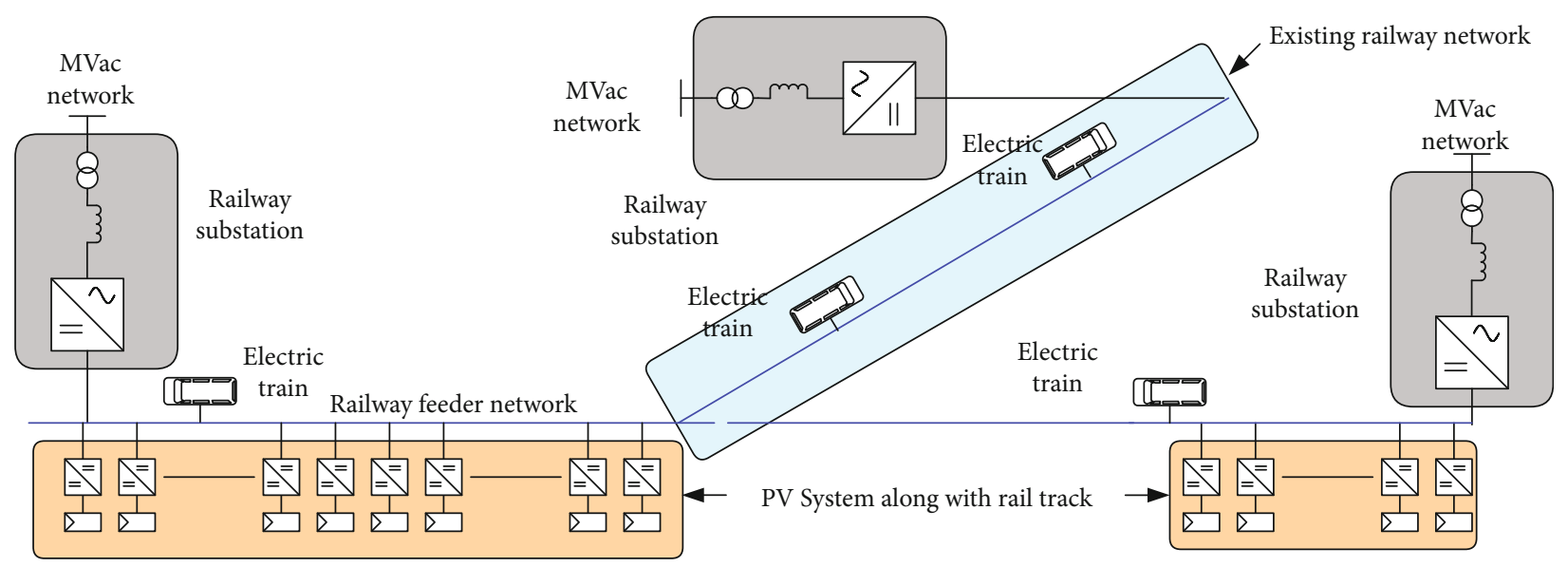

Figure 1: Proposed photovoltaic system architecture for an urban railway network.

electrification system, an electric train is powered by a cable placed along the railway network, and power is acquired from the utility through the substations placed at regular intervals. However, in the proposed railway electrification system, photovoltaic panels are mounted along the rail track. The output of the photovoltaic panels placed along the railway track can be directly integrated into the railway electrification system. Therefore, electric trains receive power from the utility and the photovoltaic system along with the railway electrification system. The energy from the photovoltaic system reduces energy consumption from the utility; thus, emissions are reduced. In addition, local photovoltaic generation helps to reduce the power losses in the railway electrification system. Since the photovoltaic system is to be implemented on land already used for the railway system, separate land is not required to implement the photovoltaic system, further reducing the environmental impact. In addition, the railway tracks, which are idling for most of the time, would be utilized. Thus, the utilization of space is significantly improved. The proposed railway electric network with photovoltaic systems will help to reduce emissions considerably.

\section{Review of Photovoltaic Systems and Railway Electrification Systems}

3.1. Railway Electrification Systems. Electric trains are comparatively more efficient than fossil fuel trains [1, 2]. Thus, the integration of electric trains throughout the globe is still increasing. Electric trains consist of traction motors that drive the train, with the rating of a traction motor ranging from $100 \mathrm{~kW}$ to several hundreds of kilowatts. Table 1 presents specifications of selected electric trains used around the world [26]. An electric train has one or more cars with traction motors, with some of the cars in a train chain without traction motors. Since the formation is different from train to train, the power requirement of an electric train varies accordingly. For example, the Kita-Osaka Kyuko Railways 9000 series consists of four motorized cars and six nonmotorized cars [28, 29].
Electric trains are driven by the power supplied from the railway electrification system. The operating voltage of the railway electrification system around the world differs from country to country. Operating voltages range from $600 \mathrm{~V}_{\mathrm{dc}}$ to $3 \mathrm{kV}_{\mathrm{dc}}$, and some systems operate at 15 or $25 \mathrm{kV}_{\mathrm{ac}}[1,4]$, $[5,26,30-33]$. Countries such as the UK operate at $750 \mathrm{~V}_{\mathrm{dc}}[1,33]$. The $1.5 \mathrm{kV}_{\mathrm{dc}}$ railway electrification system is used in countries such as the Netherlands, Japan, Hong Kong, Australia, and Denmark [1, 4, 33]. Countries such as South Africa, the Czech Republic, Slovakia, Spain, and Italy use $3 \mathrm{kV}_{\mathrm{dc}}$ systems $[1,4,33]$. Recently, it was proposed to use a $9 \mathrm{kV}_{\mathrm{dc}}$ railway electrification system. The authors in [34] propose using two feeders with $1.5 \mathrm{kV}_{\mathrm{dc}}$ and $9 \mathrm{kV}_{\mathrm{dc}}$ to improve efficiency. Furthermore, $25 \mathrm{kV}_{\mathrm{ac}} / 50 \mathrm{~Hz}$ networks are used in counties such as France, Spain, Italy, the UK, India, and the Netherlands $[1,4],[30,31] .15 \mathrm{kV}_{\mathrm{ac}} / 16.7 \mathrm{~Hz}$ is also used as the voltage and frequency of some railway electrification systems. Two main methods are used to provide electricity to the trains: (a) third rail and (b) overhead lines $[1,4,33]$. The third rail option is used in lowvoltage-operated trains operating at up to $1500 \mathrm{~V}$. Since the third rail is mounted on the railway track itself, energising with a higher voltage is unsafe. Thus, overhead lines are used for voltages above $1500 \mathrm{~V}$, with pole masts used to hang the overhead line. The distance between two pole masts can be more than 50 meters $[33,35]$. The third rail or the overhead line connects to substations at regular intervals, with the distance between two substations depending on the voltage of the railway electrification system. For $750 \mathrm{~V}_{\mathrm{dc}}$ systems, substations have to be placed at a distance less than $5 \mathrm{~km} \mathrm{[4,}$ $33,36-39]$. In the case of $1.5 \mathrm{kV}_{\mathrm{dc}}$ systems, substations are placed every $10 \mathrm{~km}[36,37]$. This gap can be $20-50 \mathrm{~km}$ for a $25 \mathrm{kV}_{\mathrm{ac}}$ system $[4,38]$.

3.2. Photovoltaic Systems. A photovoltaic panel is a device that converts solar energy into electricity. The electrical characteristics of a photovoltaic panel are nonlinear, as shown in Figure 2, and the characteristic equation is presented by Equation (1) [40]. The output current of the photovoltaic panel, photocurrent, output voltage of the photovoltaic panel, series resistance of the photovoltaic 
TABLE 1: Comparison of commuter electric trains.

\begin{tabular}{|c|c|c|}
\hline Operating voltage & Output power & Examples \\
\hline $600 / 750 \mathrm{~V}_{\mathrm{dc}}$ & $360-480 \mathrm{~kW}$ & Tokyo Metro 1000 Series \\
\hline $750 \mathrm{~V}_{\mathrm{dc}}$ & $540-680 \mathrm{~kW}$ & $\begin{array}{c}\text { Minneapolis Metropolitan Council-Tram, Sirio Florence Tram, } \\
\text { Kita-Osaka Kyuko Railways-9000 series, Bangkok Expressway and Metro Public } \\
\text { Company Limited, SMRT Trains Limited-C151 series train, Washington Metropolitan } \\
\text { Area Transit Authority (WMATA)-7000 series }\end{array}$ \\
\hline $1500 \mathrm{~V}_{\mathrm{dc}}$ & $600 \mathrm{~kW}$ & Hankyu Railways-1000 series, Tokyo Metro-1600 series, Busan Transportation Corporation \\
\hline $3000 \mathrm{~V}_{\mathrm{dc}}$ & $840 \mathrm{~kW}$ & CENTRAL 3000 Series \\
\hline $25 \mathrm{kV}_{\mathrm{ac}}$ & $960 \mathrm{~kW}$ & Caracas Suburban Railway \\
\hline
\end{tabular}
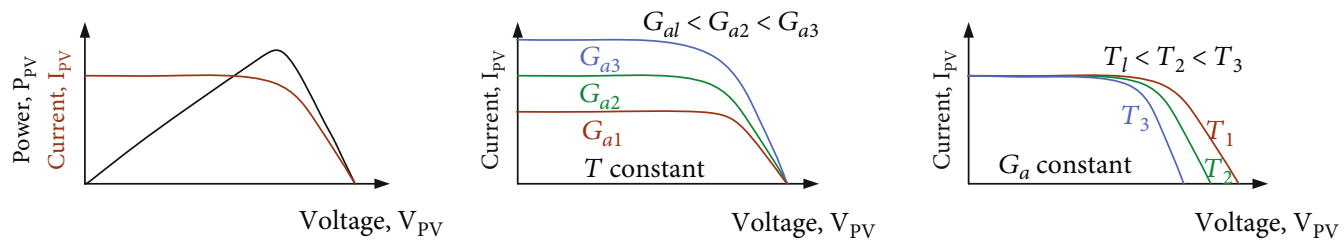

FIGURE 2: Characteristics of a photovoltaic cell.

panel, and the number of cells in the panel are given by $I_{\mathrm{pv}}$, $I_{\mathrm{Ph}}, V_{\mathrm{pv}}, R_{\mathrm{s}}$, and $N$, respectively. The output characteristics depend on the incident irradiance on the cell $\left(G_{\mathrm{a}}\right)$ and the temperature of the cell $(T)$, as presented in Figure 2 [40]. As the irradiance increases, the output power increases, while the temperature increase lowers the output power. Typically, photovoltaic panels are connected to the load via a power electronic converter. The controller of the converter ensures that each photovoltaic panel is operating at the maximum power point to extract maximum power output from each panel every instant.

$$
I_{\mathrm{pv}}=I_{\mathrm{ph}}-\exp \left(\frac{V_{\mathrm{pv}}+R_{\mathrm{s}} I_{\mathrm{pv}}}{N}\right)
$$

The open-circuit voltage and short-circuit current vary with the panel's temperature and the irradiance incident on a panel. The corresponding relationships are presented in Equations (2) and (3) [40]. Irradiance mainly impacts the short-circuit current, and the temperature impact is mainly on the open-circuit voltage. The irradiance, short circuit current, temperature coefficient for the short circuit current, temperature, open-circuit voltage, and temperature coefficient on the open-circuit voltage are given by $G_{\mathrm{a}}, I_{\mathrm{sc}}$, $\Delta I_{\mathrm{sc}}, T, V_{\mathrm{oc}}$, and $\Delta V_{\mathrm{oc}}$, respectively. The variables with additional subscript " $\mathrm{s}$ " represent the values at the Standard Test Conditions (STC). The cell temperature $(T)$ can be ascertained from the incident irradiance on the panel and the environmental temperature. Ambient temperature and nominal operating cell temperature (NOCT) are related to irradiance and environmental temperature $\left(T_{\mathrm{a}}\right)$ as given by Equation (4) [41].

$$
I_{\mathrm{sc}}=\frac{G_{\mathrm{a}} I_{\mathrm{scs}}}{G_{\mathrm{as}}}\left[1+\frac{\Delta I_{\mathrm{sc}}}{I_{\mathrm{scs}}}\left(T-T_{\mathrm{s}}\right)\right] \text {, }
$$

$$
\begin{aligned}
& V_{\text {oc }}=V_{\text {ocs }}\left[1+\frac{\Delta V_{\text {oc }}}{V_{\text {ocs }}}\left(T-T_{\mathrm{s}}\right)\right], \\
& T=T_{\mathrm{a}}+\left[\frac{(\mathrm{NOCT}-20)}{800}\right] G_{\mathrm{a}} .
\end{aligned}
$$

Different sizing methods are used in different applications [41-46]. In grid-connected applications, the average energy consumption is generally considered the starting point for building a photovoltaic system for such applications [43]. The consumer decides on the tariff structure and receives benefits based on the selected tariff structure. A separate bill is provided for photovoltaic generation, or the cost of the utility bill is reduced based on photovoltaic generation during the billing period. In the case of standalone applications, extra capacity is included to even out the energy generation differences on different days, with battery storage integrated with standalone photovoltaic systems [42, 43, 45-47].

\section{Energy Requirement and in a General Railway Electrification System with the Proposed Photovoltaic System}

4.1. The Energy Requirement of a Railway Network. Figure 3 shows a general railway electrification system with electric trains operating. The total power requirement of the railway electrification system at a given instant is represented by Equation (5), where $P_{i}$ is the power consumed by the $i^{\text {th }}$ train at the time " $t$ " and the number of trains operating on the system is " $n$." The total energy requirement for the period considered from $t_{1}$ to $t_{2}$ is given by Equation (6).

$$
P_{t=t}=\sum_{i=1}^{n} P_{i}(t=t) \times k: \begin{cases}k=1, & \text { when } i^{\text {th }} \text { train is on operation, } \\ k=0, & \text { when } i^{\text {th }} \text { train is not on operation, }\end{cases}
$$




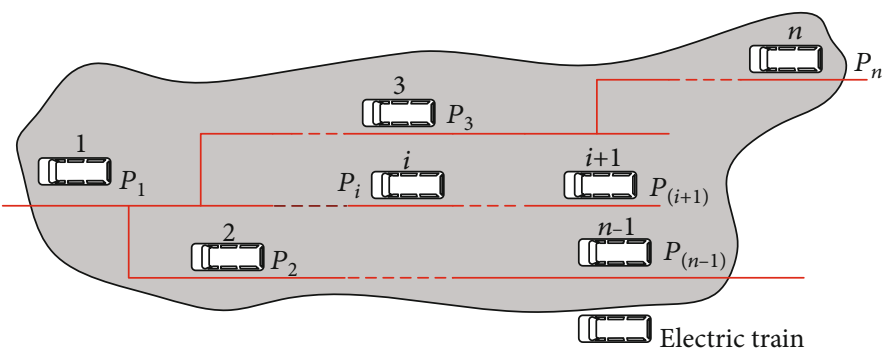

Figure 3: General railway network in closed network considered.

$$
E_{t=t_{1} \text { to } t_{2}}=\sum_{i=1}^{n} \int_{t_{1}}^{t_{2}} P_{i} d t .
$$

4.2. Energy Generation from a Photovoltaic Panel in a Particular Location. The maximum output power of a panel $\left(P_{\text {mpp }}\right)$ at a particular instance can be expressed in terms of voltage and current at the maximum power point $\left(V_{\mathrm{mpp}}\right.$ and $\left.I_{\mathrm{mpp}}\right)$ as in Equation (7). The voltage at the maximum power point of a photovoltaic panel can be expressed as a percentage of the open-circuit voltage, and similarly, the current at the maximum power point of a photovoltaic panel can be expressed as a fraction of the short-circuit current [39]. Then, the maximum output power at a given instance can be expressed as in Equation (8), where $k_{1}$ and $k_{2}$ are constants. The irradiance and temperature measurements are taken periodically, and the measurements can be assumed to be constant for the period when the period is relatively small. Then, the total energy generation for the day $\left(E_{\text {day }}\right)$ can be calculated by Equation (9), where " $T$ " and " $x$ " are the period and number of measurements per day. Assuming that the daily average is available for " $m$ " number of days of the year, the average daily energy generation $\left(E_{\text {daily,avg }}\right)$ can be calculated by Equation (10).

$$
\begin{gathered}
P_{\mathrm{mpp}}=V_{\mathrm{mpp}} I_{\mathrm{mpp}}, \\
P_{\mathrm{mpp}}=V_{\mathrm{mpp}} I_{\mathrm{mpp}}=\left[k_{1} I_{\mathrm{sc}}\right]\left[k_{2} V_{\mathrm{oc}}\right], \\
E_{\mathrm{day}}=\sum_{i=1}^{x} P_{\mathrm{mpp} @ t=i T} \times \frac{T}{60} w h, \\
E_{\text {daily,avg }}=\frac{1}{m} \sum_{i=1}^{m} E_{\mathrm{day}, i} .
\end{gathered}
$$

It is necessary to have photovoltaic measurements covering one year to establish a reliable estimation. Year-long data enables the identification of potential periods of high and low energy yield during the year. Furthermore, it is possible to calculate the number of days to generate a predefined amount of daily energy. Based on this calculation, it is possible to plot a histogram indicating the number of days of daily energy generation as a percentage of the maximum daily energy generation.

4.3. Potential Energy Yield in a Photovoltaic System of a Railway Electrification System. The electricity feeding mech- anism varies according to the voltage of the railway electrification system. Typically, the third rail is used for the trains operating at comparatively low voltage levels such as 600 or $750 \mathrm{~V}_{\mathrm{dc}}$. In this case, the photovoltaic panels can be mounted on the rail track, as shown in Figure 4. A single photovoltaic panel can be mounted on the rail track in third rail-powered railway tracks as the typical track gauge is $1400 \mathrm{~mm}$ or above. It may not be possible to mount photovoltaic panels near a railway station with multiple tracks or areas where railway signalling components are installed. The total number of photovoltaic panels that can be mounted on the railway track is given by Equation (11). There are $r$ number of segments in the railway electrification system. The length of the $i^{\text {th }}$ segment is given by $l_{\text {seg, } i}$. The length of a photovoltaic panel and the space between two adjacent photovoltaic panels are given by $l_{\mathrm{pv}}$ and $\Delta l_{\mathrm{pv}}$, respectively. Furthermore, $l_{\text {nonpv, } i j}$ is the length of the $j^{\text {th }}$ subsection where photovoltaic panels cannot be laid on the $i^{\text {th }}$ section. The number of segments where photovoltaic panels cannot be laid in the $i^{\text {th }}$ segment is taken as $y$.

$$
N_{\text {track }}=\frac{1}{\left(l_{\mathrm{pv}}+\Delta l_{\mathrm{pv}}\right)} \sum_{i=1}^{r}\left[l_{\mathrm{seg}, i}-\sum_{j=1}^{y} l_{\mathrm{nonpv}, i j}\right] \text {. }
$$

Railway electrification systems operating above $1.5 \mathrm{kV}_{\mathrm{dc}}$ typically use overhead lines to power trains. The method mentioned earlier is unsuitable, as shading of overhead lines and pole masts reduces power generation. In such situations, photovoltaic panels can be mounted above the overhead line by extending pole masts, as shown in Figure 5 . The number of panels placed along the railway track (parallel) and across the railway track (series) may vary from pole location to location. Thus, the total number of photovoltaic panels in such a system can be represented by Equation (12). $n_{\mathrm{p}}$ and $n_{\mathrm{s}}$ represent the number of panels in parallel and series at the $j^{\text {th }}$ pole of segment $i^{\text {th }}$ of the railway electrification system. It is assumed that the panels connected across the railway track form a series string, with such series strings connected in parallel along the railway track.

$$
N_{\mathrm{oh}}=\sum_{i=1}^{r} \sum_{j=1}^{p} n_{p, i j} n_{s, i j}
$$

The energy capture capability of each panel depends on the average daily energy, which corresponds to the location 


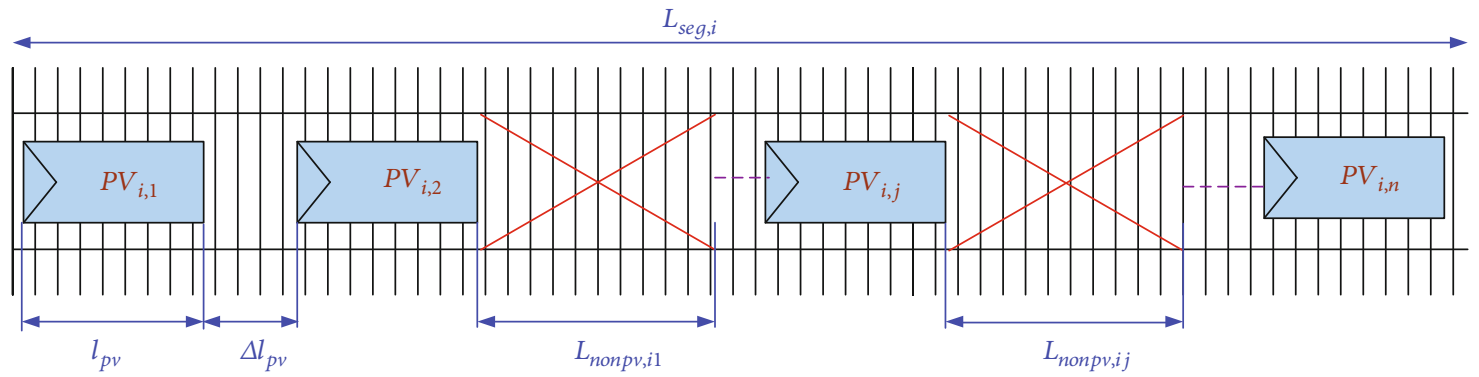

FIGURE 4: Installation of photovoltaic panels on the railway track itself.

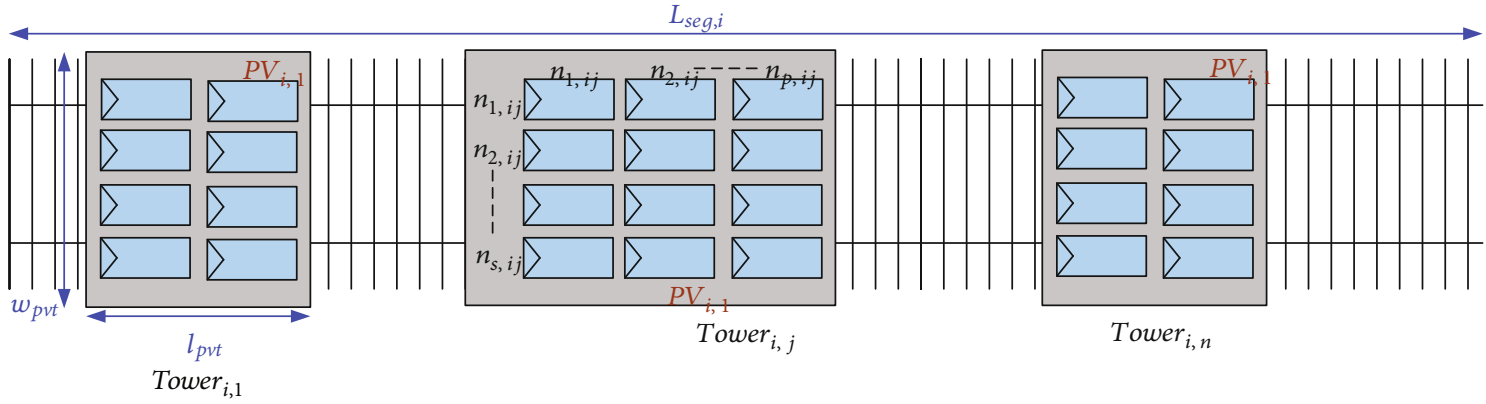

FIgURE 5: Placement of the photovoltaic panel above the overhead line using the pole mast of a railway network.

of the photovoltaic panel. Therefore, the daily average energy generation is the addition of the energy generation of each panel as in Equation (13) and which applies to the installation of photovoltaic panels on the railway track or the pole mast of overhead lines.

$$
E_{\text {total,dailyavg }}=\sum_{i=1}^{N_{\text {track }} \text { or } N_{\text {oh }}} E_{\text {dailyavg }, i} \text {. }
$$

4.4. Sizing a Photovoltaic System for a Railway Electrification System. The previous section presented a methodology to calculate the maximum number of photovoltaic panels that can be covered along a railway track. However, the capacity of the PV system depends upon the energy demand of the considered railway electrification system and the energy yield in the considered railway network that is affected by weather patterns. Thus, it is important to have a methodology to ascertain the capacity of the photovoltaic system by considering the energy demand and potential energy capture using weather data. Based on the above consideration, the proposed algorithm to size the capacity of the photovoltaic system installed along a railway electrification system is shown in Figure 6. The sizing is based on energy generation, and thus, intermittent power variations within a day are not considered.

The algorithm initially calculates the daily energy demand of trains and potential photovoltaic generation separately. The daily energy demand is calculated from the daily train operating schedule in the considered network segment. In certain locations, the overall train schedule can be classified as either essential or nonessential schedules. Essential schedules are considered as the base schedule (BS). Essential and nonessential combined operations are considered as extended schedules $(E S)$. The present and future train schedules need to be considered in selecting the base and extended schedules because investment in a photovoltaic system is for an extended period. The daily energy requirement of a train network is calculated based on Equations (5) and (6) for the considered operational schedules. The daily energy generation by a photovoltaic panel is calculated according to Equation (9) for all days where the measurements are available. Then, the potential energy generation can be calculated based on the length of the railway network segment according to Equation (13). If the potential energy requirement of the photovoltaic system on the railway network is greater than the energy requirement of the train, then a fraction of the railway network needs to be covered to meet the energy requirement so that zero emission is achieved. Otherwise, the photovoltaic system should cover the entire space, with zero emissions unachievable.

Consider the case where the potential generation is greater than the energy demand. Since the daily energy generation from a photovoltaic system differs from day to day, it is not possible to determine the exact number of photovoltaic panels required in a single attempt. Therefore, it is necessary to calculate the most appropriate capacity of the photovoltaic system. In the first approach, Equation (14) calculates the number of photovoltaic panels required by the energy demand of the rail network and the average daily energy generation of a photovoltaic panel. In the second approach, the number of days where the energy demand of the railway network can be met is considered to calculate the number of photovoltaic panels required. The daily 


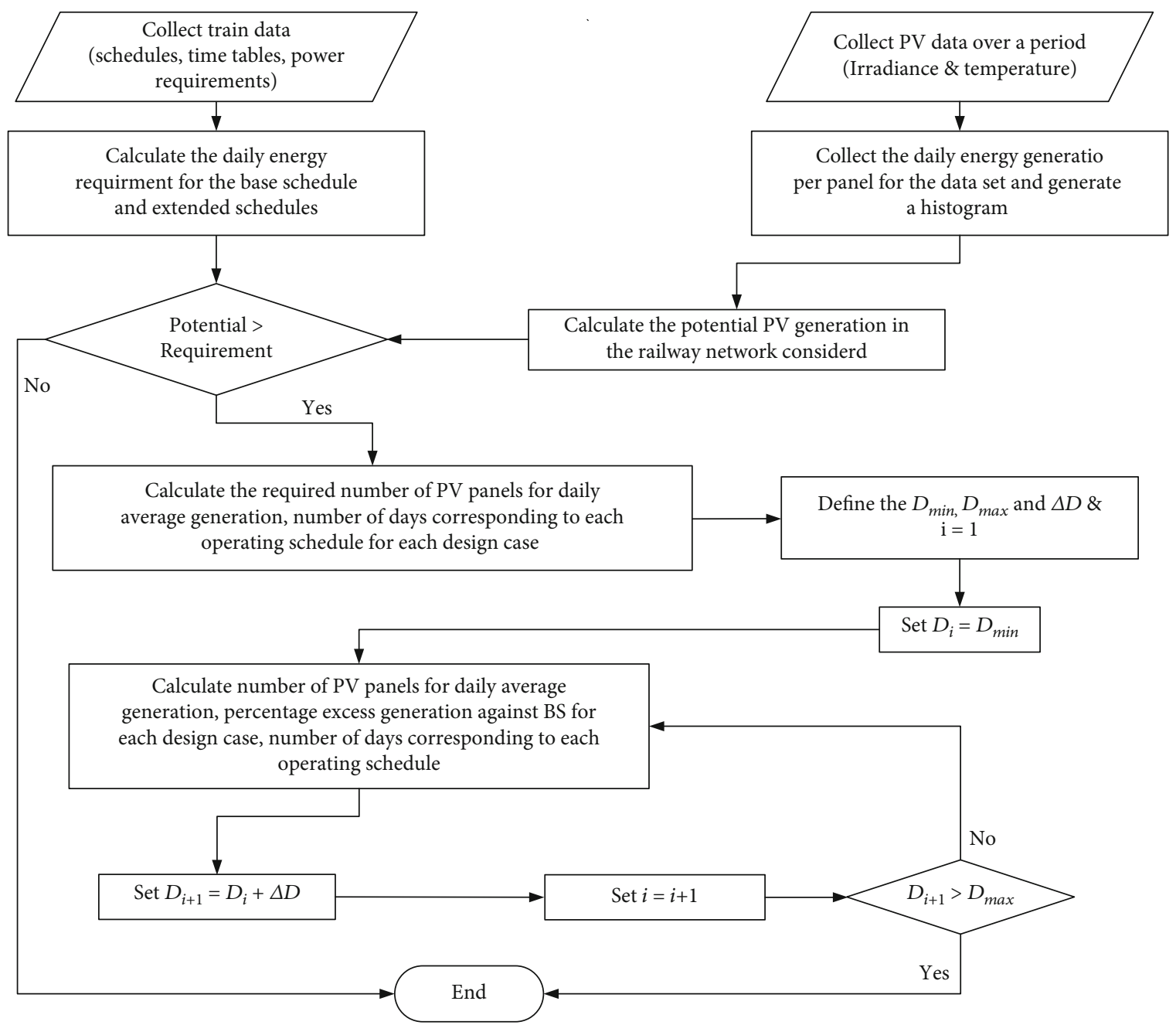

Figure 6: Photovoltaic (PV) panel sizing algorithm.

energy generations throughout the year are initially sorted in a descending order in the second approach. The minimum daily energy generation within the highest daily generation values in this sorted list for a given percentage of days is found. Let the percentage of days considered be taken as $d$. The minimum daily energy generation corresponding to the highest $d \%$ of the data set of the year is considered as

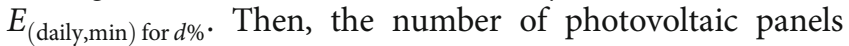
required to produce energy more than or equal to the energy demand of the railway network for $d \%$ of days can be calculated using Equation (15). The $d \%$ value can be varied to evaluate the ability of the photovoltaic system to withstand the base and extended schedules. Design cases can be defined by defining the minimum $\left(d_{\min }\right)$ and maximum $\left(d_{\max }\right)$ for the percentage of days using an appropriate increment $(\Delta d)$. In the algorithm presented in Figure 6, the BS can be selected as the energy demand of the railway network. Accordingly, it is possible to evaluate the possibility of achieving zero emissions for the essential schedules. Let $E_{\text {total,gen }}$ be the total annual energy generated from the photovoltaic systems of the railway network, and $E_{\text {total,BS }}$ is the total annual energy requirement of the railway network for the BS. The percentage of excess generation by the photovoltaic system $\left(\Delta E_{\mathrm{q}}\right)$ against the energy requirement of the train network can be calculated using Equation (16).

$$
\begin{gathered}
N_{\mathrm{PV}}=\frac{E_{t=t_{1} \text { to } t_{2}}}{E_{\text {daily,avg }}}, \\
N_{\mathrm{PV}}=\frac{E_{t=t_{1} \text { to } t_{2}}}{E_{\text {(daily,min }) \text { for } d \%}}, \\
\Delta E_{\mathrm{q}}=\left(\frac{E_{\text {Total,gen }}-E_{\text {total,BS }}}{E_{\text {total,BS }}}\right) \times 100 \% .
\end{gathered}
$$

Since the number of photovoltaic panels required for each case can be calculated by Equations (14) and (15), it is possible to estimate the daily energy generation for the data set considered. Let $E_{\text {daily,max }}$ be the maximum daily energy generation over the considered year. Then, Figure 7 illustrates the percentage number of days capable of producing more than daily energy generation for a particular daily energy value within a year for different cases. As the number of photovoltaic panels increases, the daily energy generation 
increases. Depending upon the design case, this curve varies. In Figure 7, the daily energy requirement for each scheduling case is presented, making it possible to visualize the ability of a photovoltaic system to operate in each scheduling case.

Once the above algorithm calculates the number of panels, it is possible to calculate the area to be covered on the railway track for a low-voltage DC network and the number of pole masts that need to be mounted with photovoltaic panels according to Equations (17) and (18), respectively. The percentage of area covered to full potential can be expressed as Equations (19) and (20).

$$
\begin{gathered}
l_{\mathrm{pv}, \text { total }}=N_{\mathrm{PV}} \times l_{\mathrm{PV}} \\
N_{\text {poles }}=\frac{N_{\mathrm{PV}}}{n_{\mathrm{s}} n_{\mathrm{p}}} \\
l_{\text {pv,used }}=\left[\frac{\left(\sum_{i=1}^{r} l_{\text {seg }, i}-\sum_{i=1}^{r} \sum_{j=1}^{y} l_{\text {non }, i j}\right)-l_{\mathrm{pv}, \text { total }}}{\left(\sum_{i=1}^{r} l_{\text {seg }, i}-\sum_{i=1}^{r} \sum_{j=1}^{y} l_{\text {non }, i j}\right)}\right] \times 100 \%, \\
N_{\text {poles,used }}=\left[\frac{N_{\text {poles }}-N_{\text {poles }, \text { used }}}{N_{\text {poles }}}\right] \times 100 \% .
\end{gathered}
$$

In summary, the number of photovoltaic panels in a system can be initially calculated based on the requirement of the base schedule. Then, the number of photovoltaic panels can be optimized according to excess generation requirement and the percentage of days where extended schedules are to be operated.

4.5. Performance Analysis with Scheduling Based on Daily Generation. In the previous section, the percentage for different scheduling options was calculated according to the available data. The predicted photovoltaic generation on the day ahead in the actual situation will determine a particular train operation schedule. With advancements in prediction methodologies, photovoltaic generation a day ahead can be predicted with greater accuracy. In this analysis, it is assumed that a perfect estimation can be made. The number of percentage scheduling for each option can be calculated by Equation (21), where $n_{\mathrm{si}}$ corresponds to the number of days operated in the $i^{\text {th }}$ scheduling option. Then, the amount of energy required to operate those schedules can be calculated by Equation (22), where $E_{\mathrm{s} i}$ is the energy requirement of the $i^{\text {th }}$ scheduling option and the number of scheduling options is $m$. The energy generated by the photovoltaic system for the considered period is calculated by Equation (23) where the energy generation in the $i^{\text {th }}$ day is $E_{\mathrm{day}, i}$. Finally, Equation (24) presents the percentage of effective net-zero emissions ( $\left.\mathrm{NZE}_{\text {eff }}\right)$. Zero in Equation (24) indicates perfect net-zero emissions. A negative value indicates that net-zero emissions are not met, while a positive value indicates excess photovoltaic generation.

$$
\begin{gathered}
n_{\mathrm{si} \%}=\frac{n_{\mathrm{s} i}}{d} \times 100 \%, \\
E_{\text {requirement }}=\sum_{i=1}^{m} E_{\mathrm{S} i} n_{\mathrm{S} i}, \\
E_{\text {generation }}=\sum_{i=1}^{d} \mathrm{E}_{\mathrm{day}, i}, \\
\mathrm{NZE}_{\text {eff }}=\left(\frac{E_{\text {generaton }}-E_{\text {requiremet }}}{E_{\text {requiremet }}}\right) \times 100 \% .
\end{gathered}
$$

\section{Energy Requirement and Photovoltaic System Sizing: Case Study}

5.1. The Energy Requirement of the Selected Railway Network. The train network presented in Figure 8 is selected to investigate the proposed railway electrification systems. The railway network in Kandy, Sri Lanka, was selected for the study, and there is no existing railway electrification system in this network. The selected section of the railway network can be considered as a flat terrain. Kandy (K), Gampola (G), and Kadugannawa (KG) are three termination stations. The distances from Peradeniya junction $(\mathrm{P})$ to the three destinations are $10 \mathrm{~km}, 14 \mathrm{~km}$, and $6 \mathrm{~km}$, respectively. Trains operate from Kandy to Gampola (K-G) and vice versa $(\mathrm{G}-\mathrm{K})$. Also, trains operate from Kandy to Kadugannawa $(\mathrm{K}-\mathrm{KG})$ and vice versa $(\mathrm{KG}-\mathrm{K})$. The railway track is a single track. A train with the Kita-Osaka Kyuko Railways-9000 series specifications was considered for this analysis [28, 29]. This train consists of four $170 \mathrm{~kW}$ motors. There are four motor-powered cars and six non-motorpowered cars in the original formation that could carry 1798 passengers. This formation has been modified to reduce the number of passengers on the train, with the revised formation of this train having two motor-powered cars and three nonpowered cars. The total capacity of the train is 899 passengers.

The proposed train operating pattern for the considered railway segment is presented in Figure 9. Since the objective of these electric trains is to utilize photovoltaic energy effectively, the electric train operations are limited from 06.00 to 18.00. The minimum operation of trains is presented by the letter " $B$," which is considered the base schedule (BS). The baseload consists of morning and afternoon school traffic $\left(B_{1}\right.$ and $\left.B_{4}\right)$ and office traffic $\left(B_{2}\right.$ and $\left.B_{5}\right)$ and one journey $\left(B_{3}\right)$. The base schedule was extended with additional train schedules as load-1 $\left(L_{1}\right)$, load-2 $\left(L_{2}\right)$, and load-3 $\left(L_{3}\right)$, respectively. Four operation patterns are defined as (a) base schedule: baseload only; (b) extended schedule-1 $\left(\mathrm{ES}_{1}\right)$ : baseload and load-1; (c) extended schedule-2 (ES $)$ : baseload, load-1, and load-2; (d) extended schedule-3 ( $\left.\mathrm{ES}_{3}\right)$ : baseload, load1 , load-2, and load-3.

The total power requirement for a particular instance in the considered network for each scheduling case was calculated using Equations (5) and (6) and plotted in Figure 10. 


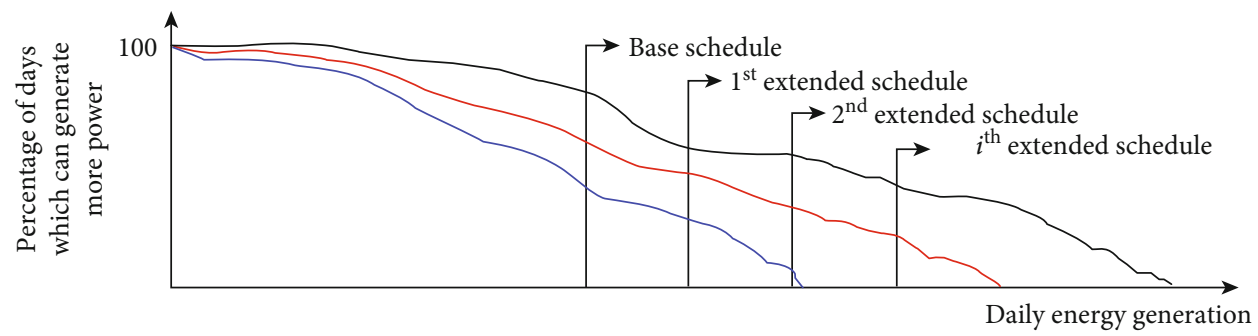

- Design case with $\mathrm{N}_{\mathrm{PV} 1}$
Design case with $\mathrm{N}_{\mathrm{PV} 2}$
Design case with $\mathrm{N}_{\mathrm{PV} 3}$
$\mathrm{~N}_{\mathrm{PV} 1}>\mathrm{N}_{\mathrm{PV} 2}>\mathrm{N}_{\mathrm{PV} 3}$

FIGURE 7: Percentage of days that can generate more energy in steps of energy generated.

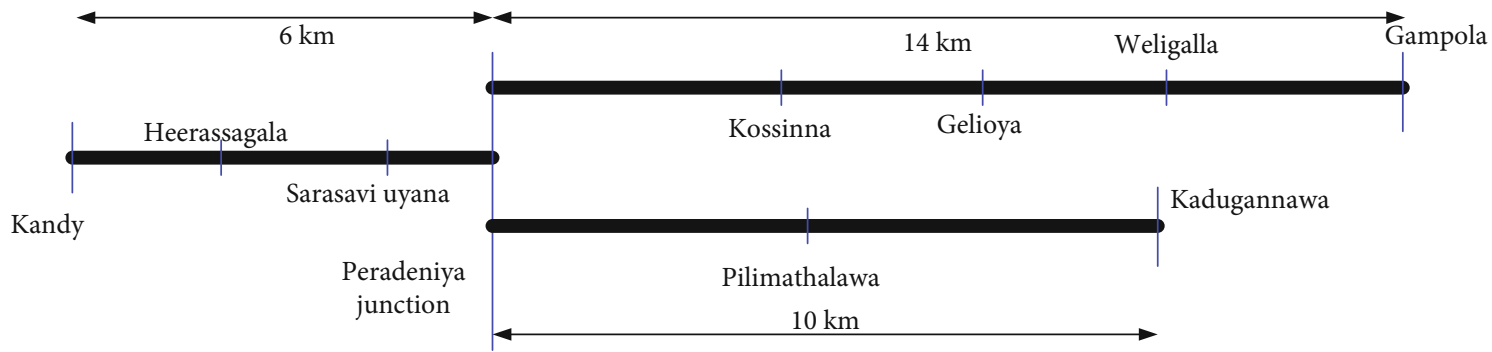

FIGURE 8: Selected railway network for the analysis.

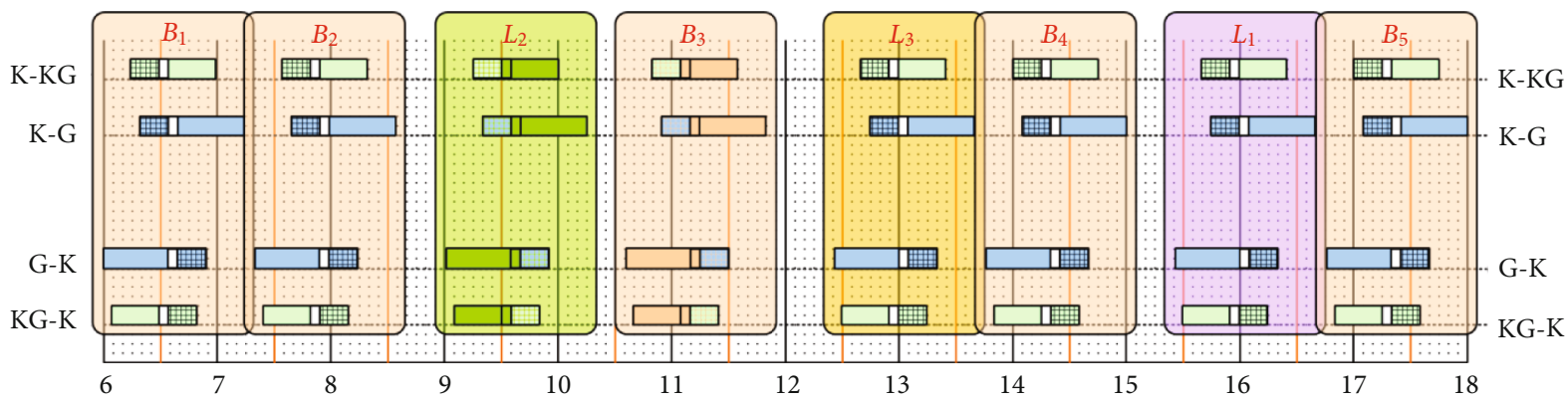

FIgURE 9: Train schedule.

Even though the power requirement varies according to the terrain and loading, the maximum power rating was considered for the photovoltaic system sizing analysis in this case. Table 2 summarizes the maximum power demand of the network and the daily energy and yearly energy demands for each scheduling case.

5.2. Photovoltaic Generation by a Panel in the Selected Location over a Year. Photovoltaic generation on the railway network varies from location to location within the considered railway network segment. However, it would be challenging to get the historical data at different locations along the selected railway network. Historical data for 2017, 2018, and 2020 were available for the location of Peradeniya in the railway network. It was assumed that variations in the environmental conditions across the network are equal to environmental conditions at Peradeniya. In this analysis, a $400 \mathrm{~W}$ photovoltaic panel is considered to estimate the energy generated from a photovoltaic panel and used to size the photovoltaic array. The specifications of the commercial photovoltaic panel considered for the analysis are shown in Table 3. Considering the datasheet values for the STC, the constants $k_{1}$ and $k_{2}$ in Equation (8) were calculated, with $k_{1}$ and $k_{2}$ equal to 0.947 and 0.832 , respectively. The panel's power output degrades by roughly $1 \%$ per year, according to the datasheet. The degradation of the photovoltaic panel's power over the years was not considered in the analysis. Using the irradiance and temperature data at Peradeniya, the energy per day is calculated using Equations (2) to (4) and (7) to (10).

Figure 11 presents the daily energy generation for 2017, 2018, and 2020. Irradiance and temperature measurements were not recorded at the data collection centre for 92, 62, and 44 days in 2017, 2018, and 2020, respectively. According 


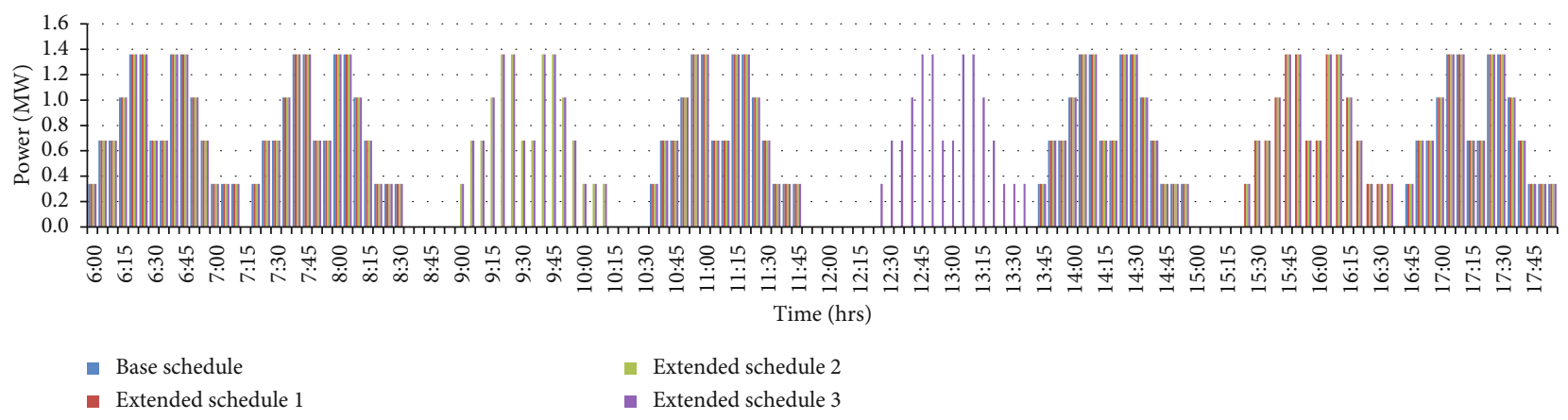

FIgURE 10: Power requirement of trains from 06:00 to 18:00.

TABLE 2: Daily energy requirement for each case.

\begin{tabular}{lccc}
\hline Case & Daily energy requirement $(\mathrm{MWh})$ & Yearly energy requirement $(\mathrm{MWh})$ & Power demand (MW) \\
\hline Base schedule $(\mathrm{BS})$ & 5.10 & 1862 & $0.00-1.36$ \\
Extended schedule-1 $\left(\mathrm{ES}_{1}\right)$ & 6.12 & 2334 & $0.00-1.36$ \\
Extended schedule-2 $\left(\mathrm{ES}_{2}\right)$ & 7.14 & 2606 & $0.00-1.36$ \\
Extended schedule-3 $\left(\mathrm{ES}_{3}\right)$ & 8.16 & 2978 & $0.00-1.36$ \\
\hline
\end{tabular}

TABLE 3: Specifications of the photovoltaic panel considered for the case study.

\begin{tabular}{|c|c|}
\hline Description & Value \\
\hline Maximum output power at STC (W) & 400 \\
\hline Voltage at maximum power point under STC (V) & 41.17 \\
\hline Current at maximum power point under STC (A) & 9.72 \\
\hline Open circuit voltage under STC (V) & 49.5 \\
\hline Short circuit current under STC (A) & 10.26 \\
\hline Temperature coefficient of open-circuit voltage $\left({ }^{\circ} \mathrm{C} / \%\right)$ & -0.289 \\
\hline Temperature coefficient of short-circuit current $\left({ }^{\circ} \mathrm{C} / \%\right)$ & 0.051 \\
\hline $\operatorname{NOTC}\left({ }^{\circ} \mathrm{C}\right)$ & $45 \pm 2$ \\
\hline Dimensions $(\mathrm{mm} \times \mathrm{mm} \times \mathrm{mm})$ & $2015 \times 996 \times 40$ \\
\hline
\end{tabular}

to 2018 and 2020 data, the first four months of the year produce more than 1500 Wh on most days compared to the rest of days of the year. Table 4 summarizes the daily average generation and the maximum daily generation. According to the results, it is possible to assume that four to five sun peak hours occurred on most of the days of the year. Days with sun peak hours being less than three are uncommon. In the middle of the year, the daily generation was less than the year's beginning. The daily average generation for 2017 is less than 2018 and 2020 by approximately $100 \mathrm{Wh}$, and it may be due to data not being available at the beginning of 2017.

Based on daily energy calculations for a year, a histogram was plotted with a step size of $100 \mathrm{Wh}$, as presented in Figure 12 for 2017, 2018, and 2020. The energy yield was highest in 2020 and minimum in 2017. However, in all three years, a significant number of days of the year produced more energy than $1000 \mathrm{Wh}$. Therefore, the energy yield depends on the environmental conditions of the considered year.
5.3. Potential Energy Yield in a Photovoltaic System of the Railway Electrification System. The number of photovoltaic panels placed on the selected railway electrification system can be calculated using Equations (11) and (12) for the third rail and overhead line arrangements. Furthermore, the daily average energy generation can be calculated from Equation (13). In the case of the third rail option, the following specifications were considered. The total length of the tracks in the network, length of each photovoltaic panel, and spacing between two photovoltaic panels are taken as $30 \mathrm{~km}, 2 \mathrm{~m}$, and $1 \mathrm{~m}$, respectively. Furthermore, there are 11 railway stations on the route, with $100 \mathrm{~m}$ allocated for each station without photovoltaic panels. Also, another $1 \mathrm{~km}$ was deducted for other exclusions. The maximum number of photovoltaic panels mounted on the network is 9300, as given in Table 5. The average daily energy generation of the photovoltaic system with 9300 photovoltaic panels is more than twice the energy requirement of $\mathrm{ES}_{2}$. Concerning placing photovoltaic panels above the overhead line, it was assumed that five panels could be placed across the railway 


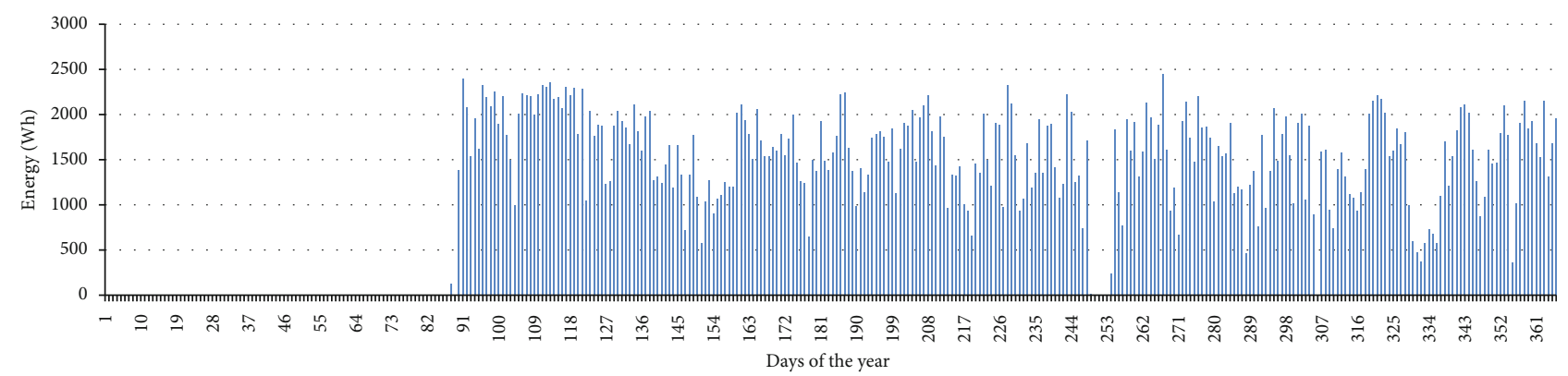

(a)

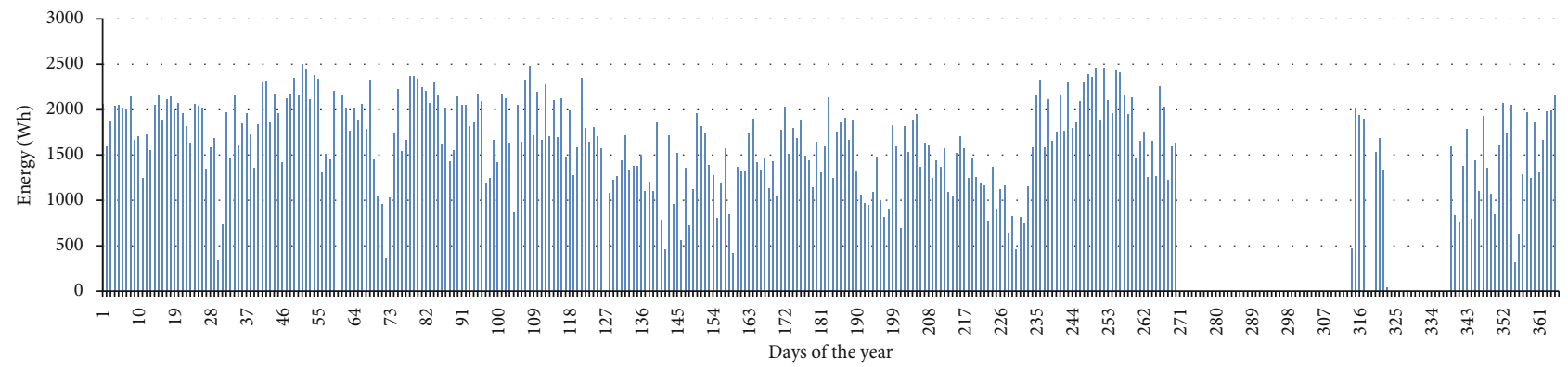

(b)

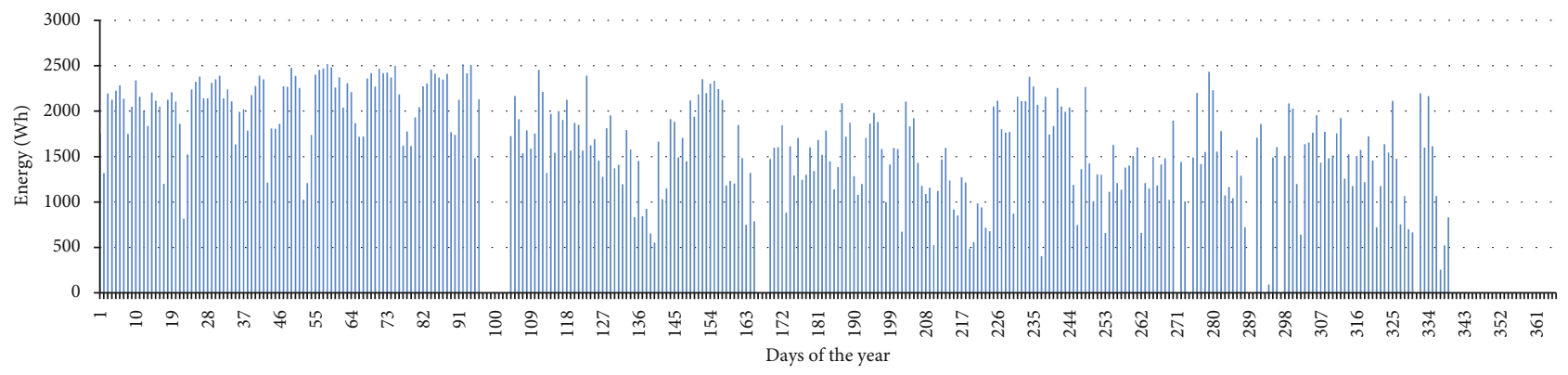

(c)

Figure 11: Daily energy generation for the years: (a) 2017, (b) 2018, and (c) 2020.

TABle 4: Comparison for energy generation of years 2017, 2018, and 2020 .

\begin{tabular}{lccc}
\hline Description & $\begin{array}{c}\text { No. of days-data } \\
\text { logged in the year }\end{array}$ & $\begin{array}{c}\text { Average } \\
\text { energy (Wh) }\end{array}$ & $\begin{array}{c}\text { Maximum } \\
\text { energy (Wh) }\end{array}$ \\
\hline 2017 & 273 & 1560 & 2454 \\
2018 & 303 & 1622 & 2497 \\
2020 & 322 & 1673 & 2518 \\
\hline
\end{tabular}

track to form a series string. Pole masts were also assumed to be located $100 \mathrm{~m}$ apart; therefore, the total number of pole masts equals 300. The number of photovoltaic panels required for different numbers of series strings is presented in Table 5. When three series strings are connected along the railway track, the average daily generation of the photovoltaic system is greater than the energy requirement of $\mathrm{ES}_{2}$. The energy requirement of the $\mathrm{ES}_{3}$ train schedule can be met on average by installing four series strings.

The areas required for the photovoltaic panels are also presented in Table 5 . The results show that by covering the space over the railway track, the energy generation from the photovoltaic system would be much higher than the energy requirement of the railway electrification system. Thus, further sizing of the photovoltaic capacity can be ascertained using the algorithm presented in Figure 6.

5.4. Sizing the Photovoltaic System for the Selected Railway Electrification System. Since the potential energy generation is higher than the energy requirement of the railway network, the photovoltaic system can be sized according to the algorithm in Figure 6. Eight design cases were considered to size the photovoltaic system and Equations (14) and (15). In design case $1\left(\mathrm{DC}_{1}\right)$, the photovoltaic system is designed so that the energy requirement of the railway electrification system based on the average daily photovoltaic generation of a panel, with Equation (14) used for the calculation. The other cases were defined by varying the percentage value used in Equation (15). d\% value was varied from $50 \%$ to $80 \%$ at $5 \%$ increments. Cases $2,3,4,5,6,7$, and 8 correspond to $d \%$ values of $80 \%, 75 \%, 70 \%, 65 \%, 60 \%, 55 \%$, and $50 \%$, respectively.

The number of photovoltaic panels required for the eight cases was calculated separately for 2017, 2018, and 


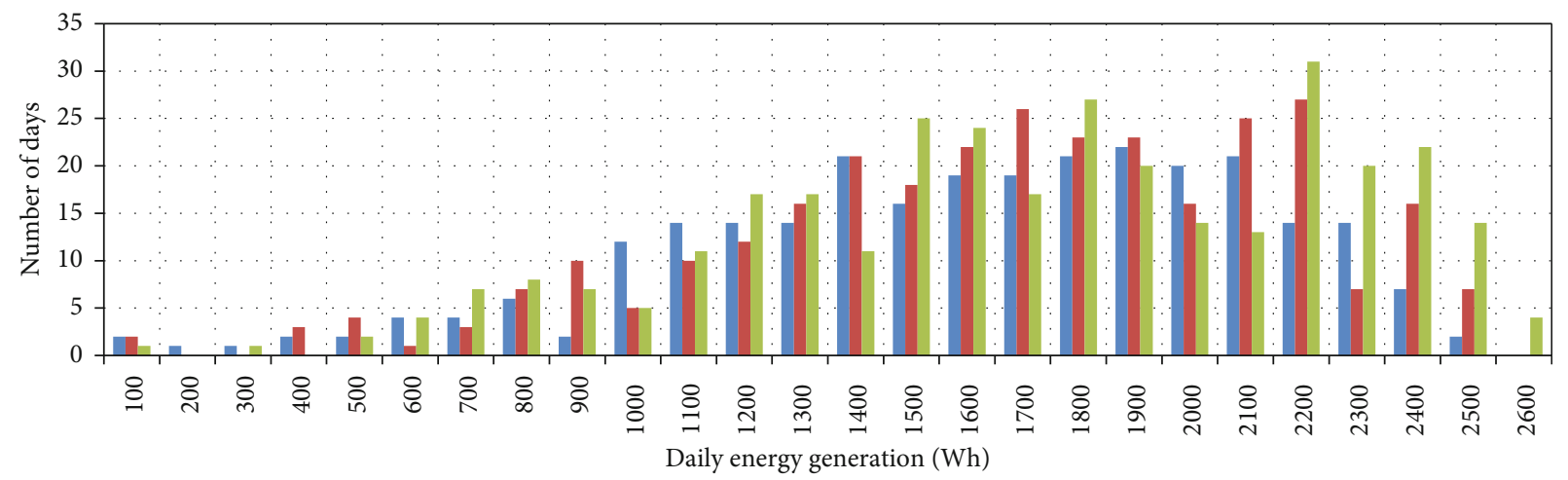

$$
\begin{array}{r}
2017 \\
\square \\
2018 \\
-2020
\end{array}
$$

FIgURE 12: Comparison of energy generation of three years (2017, 2018, and 2020).

TABLE 5: Number of photovoltaic (PV) panels and energy generation of different options.

\begin{tabular}{lccc}
\hline Case & No. of panels & Average daily generation $(\mathrm{MWh})$ & 15.30 \\
\hline PV panel on the rail track & 9300 & 2.48 & 18664 \\
PV panels above the overhead line $\left(n_{\mathrm{p}}=1\right)$ & 1500 & 4.95 & 3010 \\
PV panels above the overhead line $\left(n_{\mathrm{p}}=2\right)$ & 3000 & 7.43 & 9.90 \\
PV panels above the overhead line $\left(n_{\mathrm{p}}=3\right)$ & 4500 & 12.40 & 1020 \\
PV panels above the overhead line $\left(n_{\mathrm{p}}=4\right)$ & 6000 & 14.90 & 15052 \\
PV panels above the overhead line $\left(n_{\mathrm{p}}=5\right)$ & 7500 & 9000 & 18062 \\
PV panels above the overhead line $\left(n_{\mathrm{p}}=6\right)$ & & \\
\hline
\end{tabular}

TABLE 6: Comparison of the number of photovoltaic panels required for the cases considered.

\begin{tabular}{lcccccc}
\hline Description & \multicolumn{3}{c}{ Energy $(\mathrm{kWh})$} & \multicolumn{3}{c}{ No. of PV panels } \\
& 2017 & 2018 & 2020 & 2017 & 2018 & 2020 \\
\hline Average (DC $)$ & 1559.7 & 1622.1 & 1672.9 & 3270 & 3145 & 3049 \\
$80 \%\left(\mathrm{DC}_{2}\right)$ & 1138.1 & 1238.7 & 1202.2 & 4482 & 4118 & 4243 \\
$75 \%\left(\mathrm{DC}_{3}\right)$ & 1237.6 & 1312.1 & 1300.1 & 4121 & 3887 & 3923 \\
$70 \%\left(\mathrm{DC}_{4}\right)$ & 1322.0 & 1377.8 & 1430.0 & 3858 & 3702 & 3567 \\
$65 \%\left(\mathrm{DC}_{5}\right)$ & 1386.6 & 1464.1 & 1490.3 & 3679 & 3484 & 3423 \\
$60 \%\left(\mathrm{DC}_{6}\right)$ & 1482.3 & 1524.3 & 1566.2 & 3441 & 3346 & 3257 \\
$55 \%\left(\mathrm{DC}_{7}\right)$ & 1541.9 & 1610.9 & 1614.0 & 3308 & 3166 & 3160 \\
$50 \%\left(\mathrm{DC}_{8}\right)$ & 1608.4 & 1657.3 & 1717.4 & 3171 & 3078 & 2970 \\
\hline
\end{tabular}

2020 and presented in Table 6. The average daily photovoltaic generation in 2017 is $1559.7 \mathrm{kWh}$, and therefore, 3270 photovoltaic panels are required to meet the daily energy demand of the BS. When the daily energy generations of 2017 are sorted in a descending order, the minimum energy generation of the top $80 \%$ of daily energy generations in 2017 corresponds to $1138.1 \mathrm{kWh}$. Thus, the number of photovoltaic panels required to meet the energy demand of the BS is 4482. Similarly, for other cases concerning 2017, the number of photovoltaic panels required was calculated. Also, the number of photovoltaic panels required when considering 2018 and 2020 data was calculated separately and presented in Table 6. Due to the variation of environmental conditions, the number of photovoltaic panels required varies for each case. Since 2020 has a good energy yield, the number of photovoltaic panels required is less than the number of panels required for the other two years.

Table 7 presents the percentage excess generation compared to the energy demand of the railway electrification system operating with BS for the considered year, calculated by Equation (16). According to Table 6, 3270 photovoltaic panels are required for $\mathrm{DC}_{1}$ using 2017 data. If a 3270panel photovoltaic system is used, the yearly excess generation of the photovoltaic system in 2018 and 2020 is $4.0 \%$ and $7.3 \%$, respectively. For $\mathrm{DC}_{1}, 3145$-panel photovoltaic system is required using 2018 data. Then, the excess yearly generation of the photovoltaic system would be $-3.8 \%$ and $3.2 \%$ in 2017 and 2020. The negative percentage indicates that the BS yearly generation requirement would not be met in 2017 with the 3145-panel photovoltaic system. The percentage of excess generation for all the other cases is presented in Table 7 . It is not possible to get $10 \%$ of excess generation for the $\mathrm{DC}_{1}, \mathrm{DC}_{6}, \mathrm{DC}_{7}$, and $\mathrm{DC}_{8}$ cases. Therefore, the possibility of operating extended schedules is slim for those cases. Concerning DC 5 , design based on 2017 data will yield over $10 \%$ of excess generation. However, the percentage of excess generation would be less than $10 \%$ in some 
TABLe 7: Percentage excess generation with number of panels calculated based on 2017, 2018, and 2020 data.

\begin{tabular}{lccccccccc}
\hline & \multicolumn{3}{c}{2017 data-based design } & \multicolumn{3}{c}{2018 data-based design } & \multicolumn{3}{c}{ 2020 data-based design } \\
& $\Delta E_{2017}$ & $\Delta E_{2018}$ & $\Delta E_{2020}$ & $\Delta E_{2017}$ & $\Delta E_{2018}$ & $\Delta E_{2020}$ & $\Delta E_{2017}$ & $\Delta E_{2018}$ & $\Delta E_{2020}$ \\
\hline Average (DC $)$ & 0.0 & 4.0 & 7.3 & -3.8 & 0.0 & 3.2 & -6.8 & -3.0 & 0.0 \\
$80 \%\left(\mathrm{DC}_{2}\right)$ & 37.1 & 42.6 & 47.0 & 25.9 & 31.0 & 35.1 & 29.8 & 34.9 & 39.2 \\
$75 \%\left(\mathrm{DC}_{3}\right)$ & 26.0 & 31.1 & 35.2 & 18.9 & 23.6 & 27.5 & 20.0 & 24.8 & 28.7 \\
$70 \%\left(\mathrm{DC}_{4}\right)$ & 18.0 & 22.7 & 26.6 & 13.2 & 17.7 & 21.4 & 9.1 & 13.4 & 17.0 \\
$65 \%\left(\mathrm{DC}_{5}\right)$ & 12.5 & 17.0 & 20.7 & 6.5 & 10.8 & 14.3 & 4.7 & 8.9 & 12.3 \\
$60 \%\left(\mathrm{DC}_{6}\right)$ & 5.2 & 9.4 & 12.9 & 2.3 & 6.4 & 9.8 & -0.4 & 3.6 \\
$55 \%\left(\mathrm{DC}_{7}\right)$ & 1.2 & 5.2 & 8.5 & -3.2 & 0.7 & 3.9 & -3.4 & 0.5 \\
$50 \%\left(\mathrm{DC}_{8}\right)$ & -3.0 & 0.9 & 4.0 & -5.9 & -2.1 & 1.0 & -9.2 & -5.5 & -2.6 \\
\hline
\end{tabular}

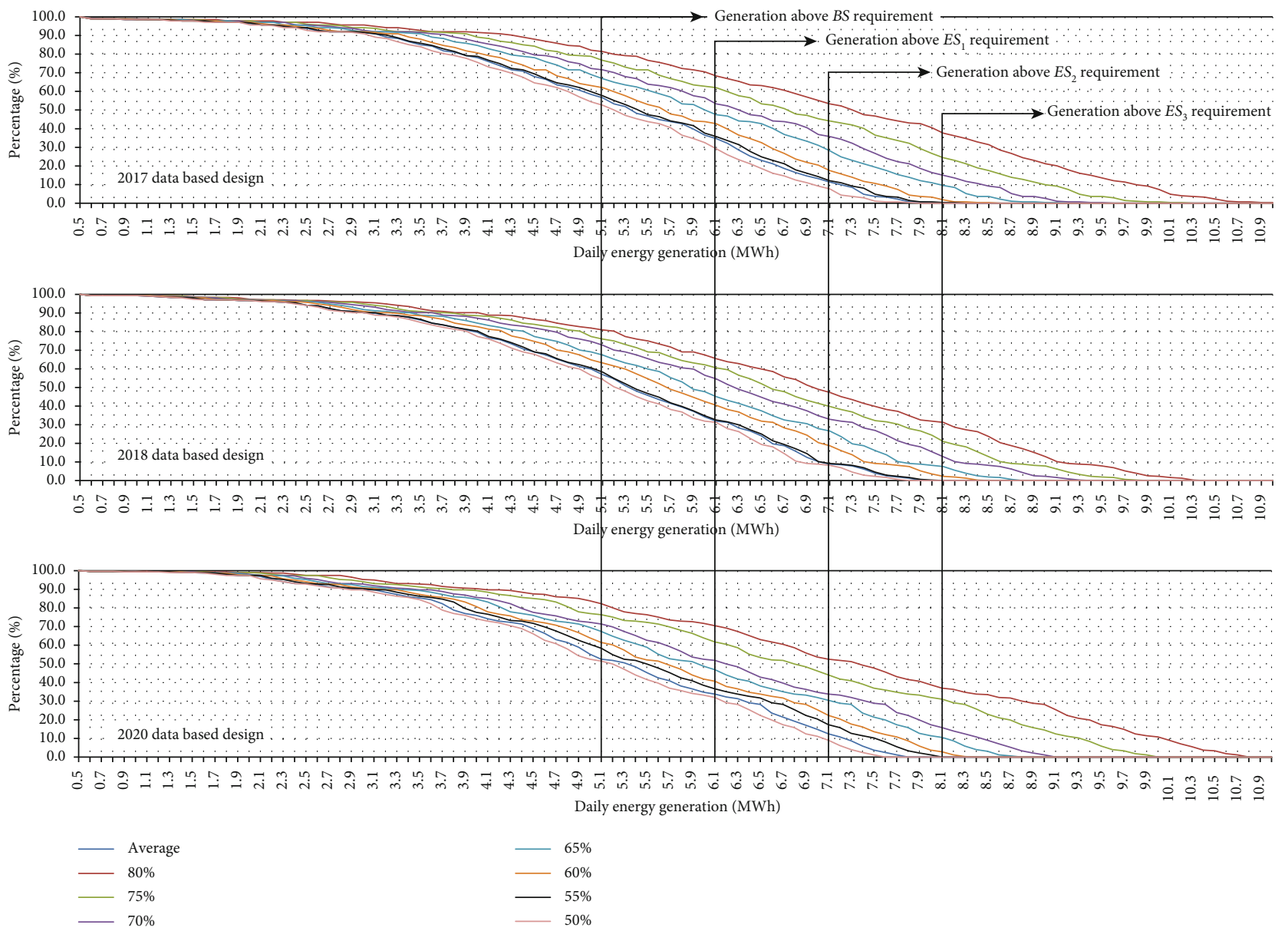

FIGURE 13: Percentage of energy generation for the years: (a) 2017, (b) 2018, and (c) 2020.

years. $9 \%-27 \%$ of excess generation would be obtained from $\mathrm{DC}_{4}$. More than $15 \%$ of excess generation would be obtained from $\mathrm{DC}_{2}$ or $\mathrm{DC}_{3}$.

Considering the results in Table 7 and design based on $\mathrm{BS}$ considered, design cases $\mathrm{DC}_{2}, \mathrm{DC}_{3}$, and $\mathrm{DC}_{4}$ generate a considerably higher percentage of excess energy while $\mathrm{DC}_{1}$, $\mathrm{DC}_{6}, \mathrm{DC}_{7}$, and $\mathrm{DC}_{8}$ may not achieve zero emissions in cases. $\mathrm{DC}_{5}$ yields positive excess generation when considering the BS yearly generation requirement for three years, irrespective of the year considered for $\mathrm{DC}_{5}$. Thus, zero emissions over a year can be achieved by implementing a photovoltaic system corresponding to $\mathrm{DC}_{5}$ for the considered years. Furthermore, the most appropriate design case can be selected depending on the appropriate percentage of excess generation value. For example, if 5\% of extra yearly generation is sufficient, $\mathrm{DC}_{5}$ based on 2018 data (3484 PV panels) or $\mathrm{DC}_{6}$ based on 2017 data (3441 photovoltaic panels) can be selected. The excess energy can be used to operate extended schedules of the railway electrification system or sold to the utility network. 
TABLE 8: Percentage of space utilization of the proposed photovoltaic systems.

\begin{tabular}{|c|c|c|c|c|c|c|}
\hline \multirow{3}{*}{ Case } & \multicolumn{6}{|c|}{ Percentage space utilization } \\
\hline & \multicolumn{2}{|c|}{2017 data-based design } & \multicolumn{2}{|c|}{2018 data-based design } & \multicolumn{2}{|c|}{2020 data-based design } \\
\hline & $3^{\text {rd }}$ rail & Overhead & $3^{\text {rd }}$ rail & Overhead & $3^{\text {rd }}$ rail & Overhead \\
\hline Average $\left(\mathrm{DC}_{1}\right)$ & 35.2 & 72.7 & 33.8 & 69.9 & 32.8 & 67.8 \\
\hline $80 \%\left(\mathrm{DC}_{2}\right)$ & 48.2 & 99.6 & 44.3 & 91.5 & 45.6 & 94.3 \\
\hline $75 \%\left(\mathrm{DC}_{3}\right)$ & 44.3 & 91.6 & 41.8 & 86.4 & 42.2 & 87.2 \\
\hline $70 \%\left(\mathrm{DC}_{4}\right)$ & 41.5 & 85.7 & 39.8 & 82.3 & 38.4 & 79.3 \\
\hline $65 \%\left(\mathrm{DC}_{5}\right)$ & 39.6 & 81.8 & 37.5 & 77.4 & 36.8 & 76.1 \\
\hline $60 \%\left(\mathrm{DC}_{6}\right)$ & 37.0 & 76.5 & 36.0 & 74.4 & 35.0 & 72.4 \\
\hline $55 \%\left(\mathrm{DC}_{7}\right)$ & 35.6 & 73.5 & 34.0 & 70.4 & 34.0 & 70.2 \\
\hline $50 \%\left(\mathrm{DC}_{8}\right)$ & 34.1 & 70.5 & 33.1 & 68.4 & 31.9 & 66.0 \\
\hline
\end{tabular}

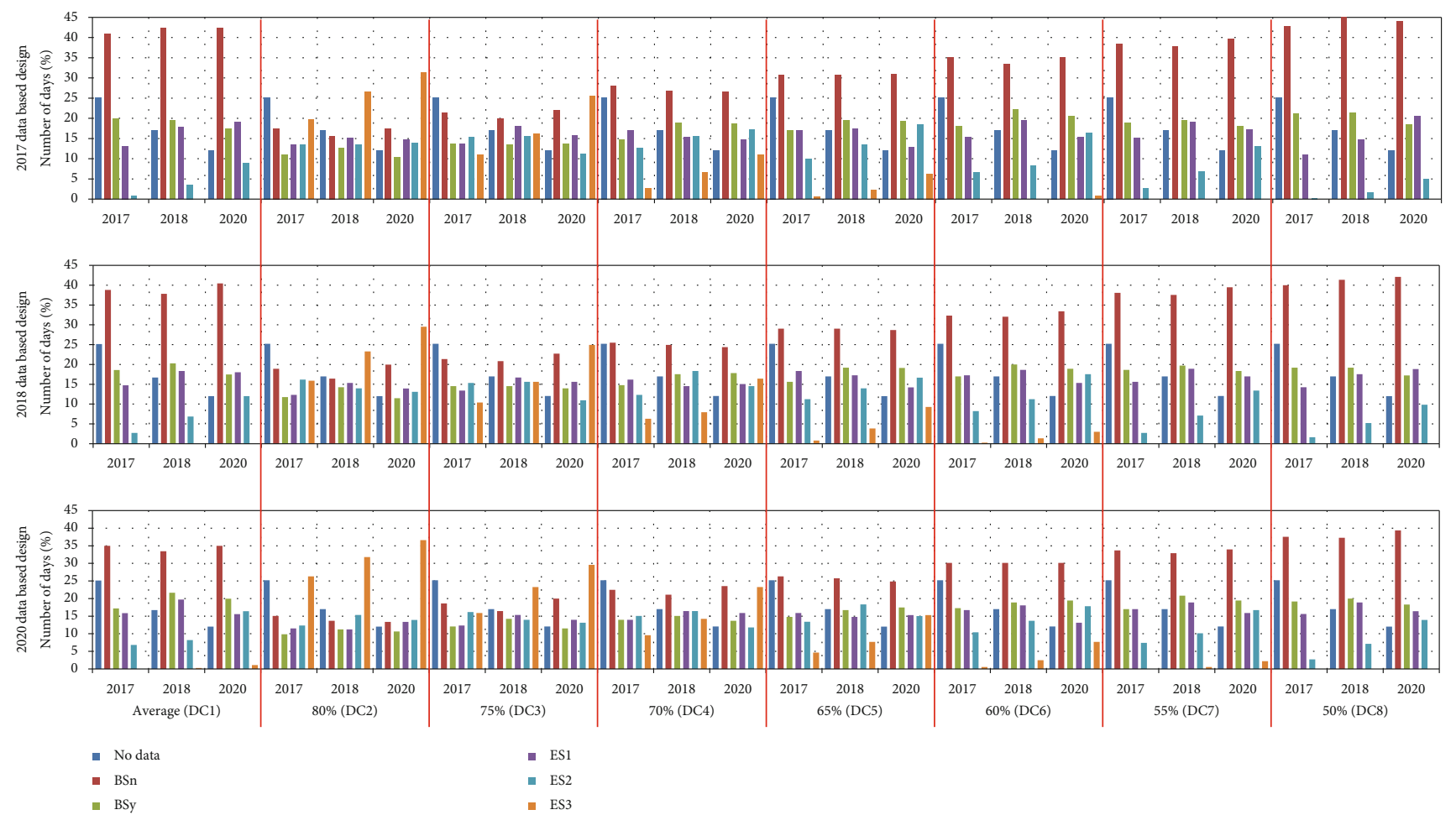

FIGURE 14: Distribution of scheduling options based on a design using 2020 data.

Figure 13 presents the histogram of the number of days compared to the daily generation for the design based on 2017, 2018, and 2020 data, respectively. The energy required for the base and extended schedules is also presented in the graphs. As the percentage of days generating energy for the base schedule increases, extended schedules can be met easily. In cases where the percentages are less than $60 \%$ and the 2017 design-based design, it would not be possible to operate $\mathrm{ES}_{3}$. Even $\mathrm{ES}_{2}$ can be met for less than $10 \%$ of the days a year. Therefore, at least designed based on above $60 \%$ should be selected if extended schedules need to be operated on significant days of the year. However, $\mathrm{ES}_{3}$ can be met for $30 \%$ of days a year a design based on $80 \%$ days. There will be days for much higher generation than the energy required for $\mathrm{ES}_{3}$ are met, which can be considered as being overdesigned.

Table 8 summarizes the percentage of space used by the proposed photovoltaic system for the considered railway electrification system. The proposed systems do not fully utilize the space available. With the third rail option, where photovoltaic panels are laid on the rail track, space utilization for the considered cases varies between 30 and $49 \%$. Assuming that the three series strings are placed parallel to the overhead rail system, $66-100 \%$ of poles would be utilized for the considered cases. There is a maximum of $5 \%$ variation on space utilization depending on the year of data used for the design. 


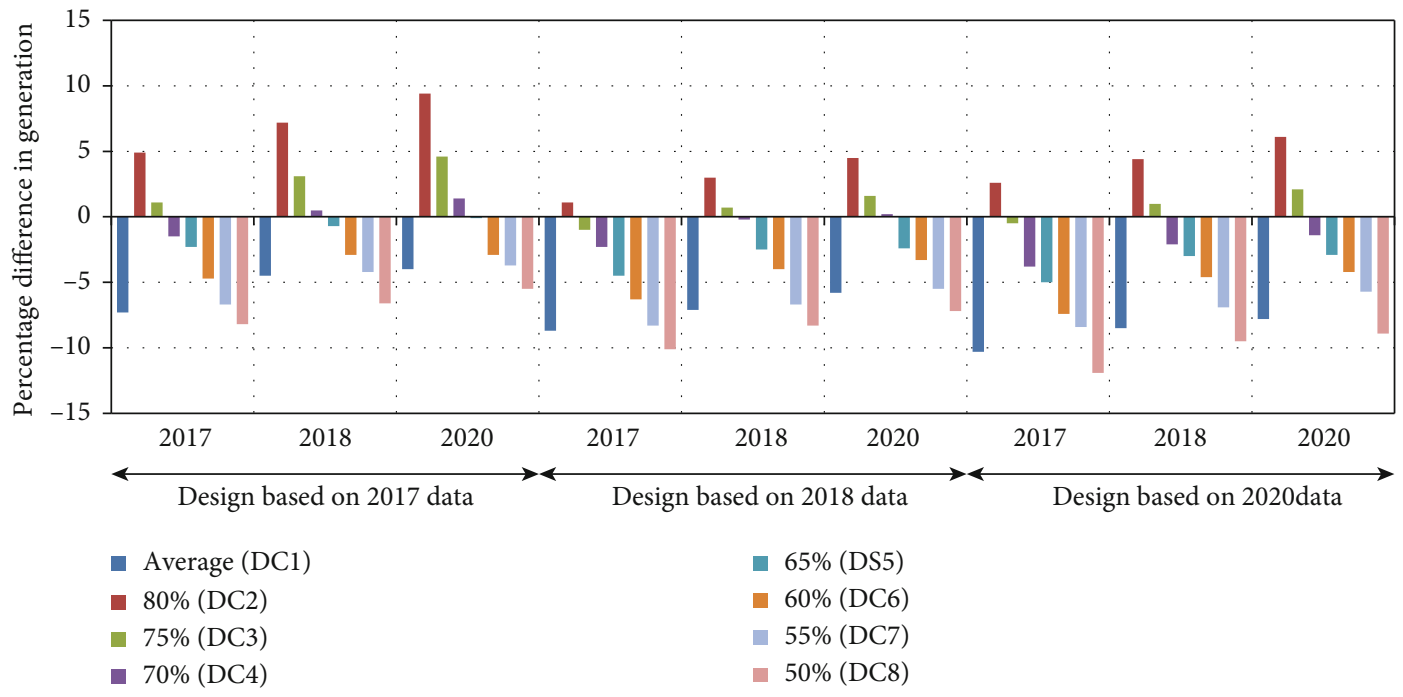

FIGURE 15: Comparison of percentage difference in generation for years 2017, 2018, and 2020 based on all scheduling options.

5.5. Performance Analysis of the System with Extended Schedules. With advances in photovoltaic generation prediction techniques, it would be possible to predict the photovoltaic energy generation day in advance with very high accuracy. Therefore, instead of having a static train schedule, dynamic scheduling can be arranged while maintaining the base schedule as the minimum requirement. Therefore, the day ahead prediction decides the operating extended schedule category (ES1, ES2, or ES3). This section analyses the ability of a photovoltaic system, which is to be implemented along with the railway network, to achieve net-zero emissions based on the railway schedule using day-ahead photovoltaic generation prediction. In this analysis, it is assumed that a perfect prediction is achieved.

Figure 14 compares the percentage of days operated on different schedules for different cases according to 2017, 2018, and 2020 data-based designs. In $\mathrm{DC}_{1}$ based on 2017 data, the BS (as indicated by BSn in the legend) energy demand was not met for approximately $40 \%$ of days in 2017. For the same case, the energy demand for the BS (as indicated by BSy) was met for $20 \%$ days of 2017. Also, energy demand $\mathrm{ES}_{1}$ (ES1 in the legend) was between 10 and $15 \%$ of the days in 2017. The energy demand for $\mathrm{ES}_{2}$ was met for approximately $1 \%$ of the days in 2017 . The energy demand for $\mathrm{ES}_{3}$ was met on any day in 2017. The following general conclusions can be drawn from the data in Figure 14. According to the results, $\mathrm{ES}_{3}$ cannot be achieved for $\mathrm{DC}_{1}, \mathrm{DC}_{7}$, and $\mathrm{DC}_{8}$. All the scheduling categories can be implemented reasonably in equal share for $\mathrm{DC}_{2}$ and $\mathrm{DC}_{3}$. In the case of $\mathrm{DC}_{4}, \mathrm{ES}_{3}$ scheduling depends on the irradiance levels received in the year, as it gets comparatively less scheduling based on the 2017 and 2018 data-based design.

Figure 15 presents the percentage difference in energy generation and demand of each year, assuming perfect predictions. Concerning 2017 with a design based on 2017 data, $\mathrm{DC}_{2}$ and $\mathrm{DC}_{3}$ would have yearly excess generation, achiev- ing net-zero emissions. For the same case, other design cases $\left(\mathrm{DC}_{1}, \mathrm{DC}_{4}, \mathrm{DC}_{5}, \mathrm{DC}_{6}, \mathrm{DC}_{7}\right.$, and $\mathrm{DC}_{8}$ ) would not meet the energy demand of the railway network. However, energy generation is within $10 \%$ of annual energy demand. Considering all the cases presented in Figure $15, \mathrm{DC}_{2}$ ensures that net-zero emissions and excess generation are achieved every year. $\mathrm{DC}_{3}$ was unable to meet zero emissions by a small percentage in 2017 when the design was used 2020 data. The energy generation deficit in $\mathrm{DC}_{4}, \mathrm{DC}_{5}, \mathrm{DC}_{6}$, and $\mathrm{DC}_{7}$ was less than $10 \%$ in 2017,2018 , and 2020 , irrespective of the design data. The deficiency in energy generation for design based on 2020 data was greater than $10 \%$ but less than $15 \%$ for $\mathrm{DC}_{1}$ and $\mathrm{DC}_{8}$ for 2017.

In conclusion, it is possible to state that the predictionbased scheduling of photovoltaic generation day ahead enables one to achieve about $90 \%$ net-zero emissions irrespective of the design case and data considered. Achieving such a level of net-zero emissions would be an outstanding achievement to safeguard the environment and achieve sustainable development. The ability to achieve the presented net-zero emission values would be less due to prediction errors in the real-world environment. Analysis of this work was conducted based on data from three years. The results indicate that data availability for a few years would allow for the effective sizing of the photovoltaic system.

\section{Conclusions}

This paper investigates the feasibility of using photovoltaic systems to operate an electric train network for an urban railway network to achieve zero emissions. Vacant space for installing the photovoltaic system is improbable in an urban area. Therefore, this study proposes using the space along the railway track to mount the photovoltaic system. There are two options available based on the voltage of the railway network. In the case of a third-rail arrangement, photovoltaic panels are proposed for mounting on the rail 
track, itself. Photovoltaic panels are proposed to be mounted above the overhead line using a pole mast in the case of the overhead-powered system. It is necessary to ensure that adequate energy is generated from the photovoltaic system for the years to achieve zero emissions. This paper presented an algorithm to size the photovoltaic system for an urban railway network considering the energy requirements of different daily scheduling and generation planning schemes. Finally, a methodology to analyse the performance of the photovoltaic system with prediction-based train scheduling was presented.

A case study based on a section of the railway network of Sri Lanka was analysed to validate the developed photovoltaic panel sizing algorithm. According to the analysis, the potential energy generation of the proposed photovoltaic system by utilizing the railway network space is more than the required amount of energy, even for the highly prioritised train schedule. The analysis was conducted using photovoltaic measurement data for 2017, 2018, and 2020. According to the algorithm results, if the design is carried out to meet $60 \%$ of the days of the year to meet the base schedule energy requirement, all the scheduling options can be realised to a satisfactory level. Finally, if the scheduling option is selected based on the prediction, zero emissions can be achieved to $90 \%$ in most cases.

The accuracy of the proposed algorithm can be improved by addressing the following aspects. In evaluating the proposed algorithm, it was assumed that the weather data of the railway network was the same over the network. However, in reality, there can be variations in the weather data on the network. Therefore, a better energy estimate can be obtained by using the weather data of several points on the railway segment. Another point for improvement is using the accurate power consumption of electric trains by considering the terrain, load on the train, and start-stop pattern over an operating cycle. It may not be possible to achieve net-zero emissions while operating based on dayahead prediction, as presented in the paper, due to realworld prediction errors. Even though the proposed photovoltaic system along the railway network is an attractive solution for achieving net-zero emissions, it would be worth evaluating the impacts on the railway electrical network, such as voltage variations and protection systems. The cost of implementation and maintenance needs to be evaluated. Further energy yield degradation over the years can be investigated to evaluate the performance of the proposed system over the lifespan of the photovoltaic system.

\section{Data Availability}

The data used for the study can be obtained from the corresponding author upon request.

\section{Conflicts of Interest}

The author declares that there is no conflict of interest regarding the publication of this paper.

\section{References}

[1] F. A. A. Rahman, M. Z. A. A. Kadir, M. Osman, and U. A. U. Amirulddin, "Review of the AC overhead wires, the DC third rail and the DC fourth rail transit lines: issues and challenges," IEEE Access, vol. 8, pp. 213277-213295, 2020.

[2] P. Cheng, H. Kong, J. Ma, and L. Jia, "Overview of resilient traction power supply systems in railways with interconnected microgrid," CSEE Journal of Power and Energy Systems, vol. 7, no. 5, pp. 1122-1132, 2021.

[3] S. Aatif, H. Hu, X. Yang, Y. Ge, Z. He, and S. Gao, "Adaptive droop control for better current-sharing in VSC-based MVDC railway electrification system," Journal of Modern Power Systems and Clean Energy, vol. 7, no. 4, pp. 962-974, 2019.

[4] netirail-wp3-d3_1-pu-v1_0-final_public.pdfJanuary 2021, http://netirail.eu/IMG/pdf/netirail-wp3-d3_1-pu-v1_0-final_ public.pdf.

[5] A. Gómez-Expósito, J. M. Mauricio, and J. M. Maza-Ortega, "VSC-based MVDC railway electrification system," IEEE Transactions on power Delivery, vol. 29, no. 1, pp. 422-431, 2014.

[6] Zero-emissions-vehicles-part-of-the-transition.pdfJanuary 2021, https://www.energy.vic.gov.au/_data/assets/pdf_file/ 0025/443086/Zero-Emissions-Vehicles-Part-Of-TheTransition.pdf.

[7] F. Ciccarelli, L. P. Di Noia, and R. Rizzo, "Integration of photovoltaic plants and supercapacitors in tramway power systems," Energies, vol. 11, no. 2, p. 410, 2018.

[8] Improving energy efficiency and reducing emissions through intelligent railway station buildings 107 , https://www.adb.org/ sites/default/files/publication/173696/energy-intelligentrailway-station.pdf.

[9] T. Igarashi, T. Kumano, H. Hayashiya, and T. Takino, "Efficiency improvement of rooftop photovoltaic system at railway station," Journal of International Council on Electrical Engineering, vol. 7, no. 1, pp. 41-50, 2017.

[10] H. Hayashiya, H. Itagaki, Y. Morita et al., "Potentials, peculiarities and prospects of solar power generation on the railway premises," in 2012 International Conference on Renewable Energy Research and Applications (ICRERA), pp. 1-6, Nagasaki, Japan, 2012.

[11] H. Hayashiya, H. Yoshizumi, T. Suzuki et al., "Necessity and possibility of smart grid technology application on railway power supply system," in Proceedings of the 2011 14th European Conference on Power Electronics and Applications, pp. 1-10, Birmingham, UK, 2011.

[12] S. Raizada and V. Verma, "Step up gain converter with fast MPPT control under moving partial shading for train rooftop PV-DC- $\mu \mathrm{G}$," in 2018 IEEE International Conference on Electrical Systems for Aircraft, Railway, Ship Propulsion and Road Vehicles International Transportation Electrification Conference (ESARS-ITEC),, pp. 1-6, Nottingham, UK, November 2018.

[13] M. Vajihi, Solar-powered light rail vehicle and tram systems, Sapienza Università di Roma, 2016, January 2021, https:// web.uniroma1.it/cdaingtrasporti/sites/default/files/ ThesisMohammad20Vajihi.pdf.

[14] mygov1535902505419392.pdf.January 2021, https://innovate .mygov.in / w p - content/uploads/2018/09/ mygov1535902505419392.pdf.

[15] “The Solar Tunnel, a Belgian railway infrastructure," January 2021, http://projects.mcrit.com/esponfutures/index.php/ principal/51-solar-tunnel. 
[16] Hungarotrain_viliJanuary 2021, http://hungarotrain.hu/eng/ vili.html.

[17] A. Ramji, S. Nagbhushan, and K. Bharadwaj, Decarbonising the Indian railways, Council on Energy, Environment and Water, India48, https://www.ceew.in/sites/default/files/ CEEW-Decarbonising-the-Indian-Railways-Policy-Brief5Apr17_1.pdf.

[18] B. Dutta, A case for solar power generation \& storage systems for Indian railways 28 , https://indianrailways.gov.in/ railwayboard/uploads/directorate/traffic_comm/RatesLetters/2017/1_\%20B\%20Dutta\%20IR\%20Conference\% 20Presentation-10-28.pdf.

[19] Y. Ying, Q. Liu, M. Wu, and Y. Zhai, "The flexible smart traction power supply system and its hierarchical energy management strategy," IEEE Access, vol. 9, pp. 64127-64141, 2021.

[20] A. Hinz, M. Stieneker, and R. W. De Doncker, "Impact and opportunities of medium-voltage DC grids in urban railway systems," in 2016 18th European Conference on Power Electronics and Applications (EPE'16 ECCE Europe), pp. 1-10, Karlsruhe, Germany, 2016.

[21] X. Zhu, H. Hu, H. Tao, and Z. He, "Stability analysis of PV plant-tied MVdc railway electrification system," IEEE Transactions on Transportation Electrification, vol. 5, no. 1, pp. 311-323, 2019.

[22] S. D’Arco, L. Piegari, and P. Tricoli, "Comparative analysis of topologies to integrate photovoltaic sources in the feeder stations of AC railways," IEEE transactions on transportation electrification, vol. 4, no. 4, pp. 951-960, 2018.

[23] W. Mingliang, W. Weiying, D. Wenli, C. Huabo, D. Chaohua, and C. Weirong, "Back-to-back PV generation system for electrified railway and its control strategy," in 2017 IEEE Transportation Electrification Conference and Expo, Asia-Pacific (ITEC Asia-Pacific), pp. 1-6, Harbin, China, 2017.

[24] J. Fabre, P. Ladoux, H. Caron et al., "Characterization and implementation of resonant isolated DC/DC converters for future MVdc railway electrification systems," IEEE Transactions on Transportation Electrification, vol. 7, no. 2, pp. 854869, 2021.

[25] X. Yang, H. Hu, Y. Ge, S. Aatif, Z. He, and S. Gao, "An improved droop control strategy for VSC-based MVDC traction power supply system," IEEE Transactions on Industry Applications, vol. 54, no. 5, pp. 5173-5186, 2018.

[26] c9TractionAndAux.pdf, 2021, https://www.toshiba.co.jp/ infrastructure/en/railway/assets/pdf/c9TractionAndAux.pdf.

[27] Intellegent Energy Europe, Design common professional framework and training methodology list of good examples of $P V$ installations, 2012, January 2021, https://ec.europa.eu/energy/ intelligent/projects/sites/iee-projects/files/projects/documents/ pvtrin_good_examples_of_pv_installations_en.pdf.

[28] Kita Osaka Kyuko 9000 series - Alchetron, the Free Social EncyclopediaJanuary 2021, https://alchetron.com/Kita-OsakaKyuko-9000-series).

[29] Our products| Kinki SharyoJanuary 2021, https://www .kinkisharyo.co.jp/english/ourproducts/?offset=20\&.

[30] A. Verdicchio, P. Ladoux, H. Caron, and C. Courtois, "New medium-voltage DC railway electrification system," IEEE Transactions on Transportation Electrification, vol. 4, no. 2, pp. 591-604, 2018.

[31] M. Popescu and A. Bitoleanu, "A review of the energy efficiency improvement in DC railway systems," Energies, vol. 12, no. 6, p. 1092, 2019.
[32] S. E. Kale and K. D. Joshi, "Railway traction system: current status and apportunities," The International Journal of Electrical Engineering \& Education, vol. 10, no. 1, pp. 47-56, 2017.

[33] "Low Cost Electrification for Branch LinesTech. Rep. 1https:// assets.publishing.service.gov.uk/government/uploads/system/ uploads/attachment_data/file/3872/low-cost-electrificationreport.pdf.

[34] A. Verdicchio, P. Ladoux, H. Caron, and S. Sanchez, "Future DC railway electrification system-go for $9 \mathrm{kV}$," in 2018 IEEE International Conference on Electrical Systems for Aircraft, Railway, Ship Propulsion and Road Vehicles International Transportation Electrification Conference (ESARS-ITEC), pp. 1-5, Nottingham, UK, 2018.

[35] A. Beagles, D. Fletcher, M. Peffers, P. Mak, and C. Lowe, "Validation of a new model for railway overhead line dynamics," Proceedings of the Institution of Civil Engineers: Transport, vol. 169, no. 5, pp. 339-349, 2016.

[36] S. Açıkbaş and M. Turan Söylemez, "Energy loss comparison between 750 VDC and 1500 VDC power supply systems using rail power simulation," WIT Transactions on The Built Environment, vol. 74, p. 10, 2004.

[37] Z. Tian, System Energy Optimisation Strategies for DC Railway Traction Power Network, University of Birmingham, UK, 2017, p. 214, https://etheses.bham.ac.uk/id/eprint/7779/1/ Tian17PhD.pdf.

[38] A. D. Femine, D. Gallo, D. Giordano, C. Landi, M. Luiso, and D. Signorino, "Power quality assessment in railway traction supply systems," IEEE Transactions on Instrumentation and Measurement, vol. 69, no. 5, pp. 2355-2366, 2020.

[39] G. Qian, J. Wang, Y. Fan, M. Zhou, M. Gong, and W. Chen, "Temporal fluctuated features of metro traction load current in DC railway," IEEE Access, vol. 8, pp. 150301-150310, 2020.

[40] P. Binduhewa, "Microsource Interface for a Microgrid," The University of Manchester, Manchester, UK, 2010, https:// www.escholar.manchester.ac.uk/jrul/item/?pid=uk-ac-manscw:86106.

[41] T. Khatib and W. Elmenreich, "An improved method for sizing standalone photovoltaic systems using generalized regression neural network," International Journal of Photoenergy, vol. 2014, 8 pages, 2014.

[42] A. Iqbal and M. T. Iqbal, "Design and analysis of a stand-alone PV system for a rural house in Pakistan," International Journal of Photoenergy, vol. 2019, 8 pages, 2019, January 2021, https:// www.hindawi.com/journals/ijp/2019/4967148/.

[43] M. A. Omar and M. M. Mahmoud, "Design and simulation of a PV system operating in grid-connected and stand-alone modes for areas of daily grid blackouts," International Journal of Photoenergy, vol. 2019, Article ID 5216583, 2019.

[44] H. Rezk, "A comprehensive sizing methodology for standalone battery-less photovoltaic water pumping system under the Egyptian climate," Cogent Engineering, vol. 3, no. 1, 2016.

[45] E. T. E. Shenawy, A. H. Hegazy, and M. Abdellatef, "Design and optimization of stand-alone PV system for Egyptian rural communities," vol. 12, no. 20, p. 14, 2017.

[46] E. Quiles, C. Roldán-Blay, G. Escrivá-Escrivá, and C. RoldánPorta, "Accurate sizing of residential stand-alone photovoltaic systems considering system reliability," Sustainability, vol. 12, no. 3, p. 1274, 2020.

[47] A. Trindade and L. Cordeiro, "Optimal sizing of stand-alone solar PV systems via automated formal synthesis," 2019, January 2021, http://arxiv.org/abs/1909.13139. 